\title{
Advances in the development paradigm of biosample-based biosensors for early ultrasensitive detection of alzheimer's disease
}

\author{
Hem Prakash Karki ${ }^{1}$, Yeongseok Jang ${ }^{1}$, Jinmu Jung ${ }^{1,2^{*}}$ and Jonghyun $\mathrm{Oh}^{1,2^{*}}$
}

\begin{abstract}
This review highlights current developments, challenges, and future directions for the use of invasive and noninvasive biosample-based small biosensors for early diagnosis of Alzheimer's disease (AD) with biomarkers to incite a conceptual idea from a broad number of readers in this field. We provide the most promising concept about biosensors on the basis of detection scale (from femto to micro) using invasive and noninvasive biosamples such as cerebrospinal fluid (CSF), blood, urine, sweat, and tear. It also summarizes sensor types and detailed analyzing techniques for ultrasensitive detection of multiple target biomarkers (i.e., amyloid beta (A $\beta$ ) peptide, tau protein, Acetylcholine (Ach), microRNA137, etc.) of AD in terms of detection ranges and limit of detections (LODs). As the most significant disadvantage of CSF and blood-based detection of AD is associated with the invasiveness of sample collection which limits future strategy with home-based early screening of $A D$, we extensively reviewed the future trend of new noninvasive detection techniques (such as optical screening and bio-imaging process). To overcome the limitation of non-invasive biosamples with low concentrations of AD biomarkers, current efforts to enhance the sensitivity of biosensors and discover new types of biomarkers using non-invasive body fluids are presented. We also introduced future trends facing an infection point in early diagnosis of AD with simultaneous emergence of addressable innovative technologies.
\end{abstract}

Keywords: Alzheimer's disease, Biosample, Biomarker, Biosensor, Early detection

\section{Introduction}

Globally, a large number of people with old age are affected by prolonged neurodegenerative diseases that can ultimately lead to Alzheimer's disease (AD), the most prevailing type of dementia [1]. Biomarker-based detection can diagnose $\mathrm{AD}$ in an early stage. These biomarkers such as amyloid beta $(A \beta)$ peptide, total tau protein $(\mathrm{t}$-tau), phosphorylated tau protein ( $\mathrm{p}$-tau), and so on are well known as good indicators of $A D$ [2]. Especially, $A \beta$ peptide produced by amyloid precursor protein (APP) can be solubilized in cerebrospinal fluid (CSF) and blood

\footnotetext{
*Correspondence: jmjung@jbnu.ac.kr; jonghyuno@jbnu.ac.kr

2 Department of Nano-bio Mechanical System Engineering, College of Engineering, Jeonbuk National University, Jeonju 54896, South Korea Full list of author information is available at the end of the article
}

plasma [3]. This biomarker enables high sensitivity and specificity in differentiating $\mathrm{AD}$ from other dementia. For this reason, various biosensing technologies are being developed using body-derived biosamples with solubilized biomarkers for early diagnose of AD.

Biomarkers present in various biosamples are key factors to identify early onset of AD. They are also helpful for the diagnosis, prognosis, and disease management process $[4,5]$. These biomolecules indicate main aspects of pathogenesis such as neuronal and axonal degenerations $[6,7]$, neurofibrillary tangle (NFT) formation with p-tau $[8,9]$, and oligomerization of beta-amyloid to form amyloid plaques in the brain [10]. A $\beta$-peptides, $t$-tau, and $\mathrm{p}$-tau proteins are the most common AD biomarkers. In 1984, a postmortem brain analysis indicated that $\mathrm{A} \beta$-peptide was the primary component that triggered 
AD. Further research has added tau protein as a second key element for neurofibrillary tangles (NFT) and the pathological hallmark of AD. Later, amyloid precursor protein (APP) on chromosome 21 was identified as the cause of the formation of $\beta$-amyloid protein. APP has a direct relationship with Down syndrome (DS). It ultimately leads to Alzheimer's disease [11]. Incessant research on $\mathrm{AD}$ has uncovered additional factors such as apolipoprotein-E (ApoE) [12] on chromosome 19, amyloid- $\beta$-derived diffusible ligands (ADDLs) [13], $\alpha-1-$ antitrypsin (AAT) [14], A disintegrin and metalloprotease 10 (ADAM10) [15], beta-secretase or beta-site APP cleaving enzyme I (BACE1) [16], and Alzheimer's disease-associated neuronal thread protein (AD7c-NTP) [17].

The diagnosis of $\mathrm{AD}$ can be carried out using different biosamples from the body, such as cerebrospinal fluids (CSF), blood, urine, tears, sweat, and saliva [18, 19]. In majority of the cases, clinical diagnosis of AD has been carried out using brain-based biosamples (i.e., CSF) because they contain high concentrations of biomarkers [20-23]. CSF is an extracellular bio-fluid in the brain. It contains major $\mathrm{AD}$ biomarkers such as amyloid beta $(\mathrm{A} \beta)$ peptide and total tau protein ( $\mathrm{t}$-tau) along with phosphorylated tau protein (p-tau) [24]. Therefore, CSF is considered as a preferred biosample that can distinctly reflect pathological or biochemical changes in the brain as $\mathrm{AD}$ progresses [25]. However, the disadvantage of using CSF is that collecting it from the back bone of the body by lumbar puncture is invasive and uncomfortable. Such collection might induce transient back-pain and headache in patients [26-28]. As an alternative, blood-based biosensing is an attractive and practical strategy for the detection of $\mathrm{AD}$ biomarkers to overcome drawbacks of CSF collection [29, 30]. Blood sample can be used for diagnosis with a small volume. It contains $A \beta$-peptide, $\mathrm{t}$-tau, p-tau, axonal neuron-specific protein neurofilament light (NFL), and other AD biomarkers [31]. Therefore, previous $\mathrm{AD}$ biosensor have mostly focused on effective detection and measurement of biomarkers from blood samples [32, 33]. A diagnostic method using blood sample is much easier than a CSF-based procedure. However, collecting blood samples is still invasive.

$\mathrm{AD}$ diagnosis would be more feasible to the general public if the detection of biomarkers can be achieved with low-cost and non-invasive techniques [34]. Noninvasive biosamples such as urine, tears, and sweat can be easily collected at the time of requirements to minimize disturbance to patients. They are attracting intensive research attention. However, since brain-released specific biomarkers are present at lower concentrations in non-invasive biosamples than in invasive samples (CSF and blood), an enhanced ultrasensitive detection of $\mathrm{AD}$ biomarkers using those non-invasive biosamples is required condition [35-40]. Urine, a non-invasive sample, is the product of blood filtration through the kidney. It contains different bio-components such as electrolytes, metabolites, and hormones. Different pathological evidences have indicated that a biomolecule 8-hydroxy2-deoxyguanosine (8-OHdG) produced by oxidative damage of DNA is a significant biomarker in the urine of $\mathrm{AD}$ patients [41]. AD patients' urine show higher levels of 8-OHdG than those of healthy individuals [42]. Similarly, the lacrimal apparatus produces tear, a watery fluid that oozes out from eyes. Tears contain different components such as electrolytes, lipids, and proteins that could be potentially used as disease indicators [43]. Many research and investigations are going on extensively to identify reliable relationships between tear biomolecules and human diseases [44]. Studies of tear biomarkers are shifting from traditional investigation approaches to more advanced technologies. Enzyme-linked immunosorbent assay (ELISA) and protein-chip arrays are some of commonly used modern techniques for the detection of $\mathrm{AD}$ biomarkers in tear samples [45, 46]. Human body produces a watery liquid that is well-known as sweat from the skin surface generally when the body faces an excessive physical exercise. It could be used as an important non-invasive biosample to monitor health condition of the body in a very easy way as it contains different types of electrolytes and biomolecules. For example, sodium ion present in sweat sample could be used to monitor and detect the disease progression of $\mathrm{AD}$.

$\mathrm{AD}$ indicates that the appearance of neuropathological hallmarks in the body occurs more than one decade before the actual appearance of clinical symptoms $[47,48]$. Advanced biosensor technology provokes the diagnosis of $\mathrm{AD}$ before the actual appearance of pathological symptoms. It plays a significant role in prompt management of the disease. The quality of the effective biosensors can be assessed with the reproducibility, accuracy, sensitivity, and stability of the sensor platform as well as its sensing results. Accuracy can be obtained by comparing the sensitivity of sensor platform with the gold standard method established for that particular biomarkers [49]. Contemporarily investigated and designed advanced biosensor platforms showed the improved accuracy, reproducibility, and stability for the detection of $\mathrm{AD}$ biomarkers from different body fluids samples. Therefore, the modern biosensor devices are designed to fulfil the demand of point-of-care guidelines with the enhanced accuracy performance [50]. Early detection of AD biomarkers using highly selective and ultrasensitive biosensors can be a significant step to alleviate diseases. Previously, the most commonly used ELISA method also known as INNOTEST assay has been applied for the detection of t-tau, p-tau, 
and A 342 in CSF samples [51, 52]. The use of capillary electrophoresis, western blotting, northern blotting, microRNA array technique, and real-time reverse transcription polymerase chain reaction is becoming popular for the detection of $A \beta$-peptides, tau proteins, and microRNA biomarkers [37]. An effective biosensor comprises different components successfully assembled for the ultrasensitive and highly selective detection of targeted biomarker analyte from biosamples as shown in Fig. 1, reprinted with permission from ref. [34]. With increasing prevalence of $\mathrm{AD}$, there is a towering demand for a new approach of AD diagnosis using non-invasive methods. Biosensor techniques are highly effective and sensitive for real-time detection of biomarkers or biomolecules through an in vitro or in vivo process [53, 54]. Immuno-magnetic reduction (IMR) and/or single-molecule array (Simoa), mass spectrometry, and immunoassay tools are frequently used for the detection and measurement of biomarkers $[55,56]$. Existing neuroimaging tools and neuropsychological tests are very expensive and out of reach for common people [57]. Therefore, cost-effective, miniaturized, and portable biosensors with easy handling procedure even by low-skilled general public show great value for the diagnosis and management of $\mathrm{AD}[58,59]$.

This review highlights development, challenges, and future directions of biosensors using both invasive and non-invasive biosamples for early diagnosis of $\mathrm{AD}$ biomarkers. We provide the change of analytical performance criteria related to the progress of biosensors depending on biomarker detection scale (such as femto, nano, and micro) using different biosample types. It might be helpful to derive optimal ideas on the design, fabrication, and testing strategy for ultrasensitive biosensors to facilitate early detection of AD biomarkers in different biosamples.

\section{Detection of AD biomarkers in biosamples}

There are various types of body fluids (blood, breath, CSF, interstitial fluid, nipple aspirate fluid, saliva, seminal fluid, stool, sweat, tear, and urine) as shown in Fig. 2A that may be used for the detection of AD biomarkers. Among these diverse body fluids, several specific body fluids containing AD biomarkers can be used to determine the progression of $\mathrm{AD}$ along with the advancement of biosensor technology.

Medical history has shown that brain-based components, mainly brain tissue, brain extract, and CSF, can be used at the very initial time to diagnose and monitor neurodegenerative diseases [60]. CSF is one of important biosamples used to diagnose AD. It can function as an indicator of any pathological changes in and around the brain or neural tissues [61]. Roche Diagnostic center has developed with a fully automated, precise, accurate, reliable and reproducible next-generation Elecsys assay platform, Roche cobas e601 analyzer, for the detection of CSF A 342 , t-tau, and p-tau [62, 63]. This is an electrochemiluminescence immunoassay with quantitative sandwich principle and possesses the total assay time within 18 minutes. The measurement of $A \beta$ peptides in CSF of AD patients could be very useful for drug development and clinical control. Disruption and permeability of the blood-brain barrier (BBB) increase with age [64]. Similarly, neurodegenerative disorders allow the infiltration of short peptide biomolecules such as $A \beta$ peptides from the brain to the blood [65]. Therefore, blood samples also show the presence of important biomarkers, including $A \beta$ peptides, $t$-tau, $p$-tau, and NFL (Fig. $2 B$ ). These $A \beta$ peptide, $t$-tau protein, and $p$-tau proteins are the most promising biomarkers for the diagnosis of $\mathrm{AD}$ [66].

However, collecting CSF and blood samples are invasive mode, the recent studies have focused on early diagnosis of $\mathrm{AD}$ using non-invasive biosamples containing $\mathrm{AD}$ biomarkers. Urine is a potential biosample for the detection of $\mathrm{AD}$ biomarkers. The production of some specific biomarkers or biomolecules from the metabolism of proteins and lipids may indicate health condition of a person [68]. Hartmann et al. have used urine to detect AD biomarkers. Significant urine biomarkers include 8,12-iso-iPF $2 \alpha-\mathrm{VI}$, total free amino acids, glycine, and 8-OHdG, with detected accuracy of $90 \%[30,69]$. Isoprostane 8,12 -iso-iPF $2 \alpha-\mathrm{VI}$ is a product of lipid peroxidation. Its concentration is increased in $\mathrm{AD}$ patients than in healthy controls [70]. Another study has reported that the level of an inhibitory neurotransmitter in the spinal cord, a free amino acid known as glycine, increases in AD patients [71]. Additionally, 8-OHdG has been reported as a critical $\mathrm{AD}$ biomarker in urine of patients. It is produced from the breakdown of guanine base of DNA by excited oxygen species [42, 72]. AD can also affect the entire visual capacity of a patient along with visual pathways and the visual cortex due to the deposition of $A \beta$ peptides on walls of lens and retina [73, 74]. Therefore, tear is another important biosample containing relatively high protein contents [75] that could be used for the diagnosis of AD. Moreover, biomarkers such as lipocalin-1, dermcidin, lysozyme-C, lactotransferrin, defensins, LL-37 cathelicidin, and lacritin, could be used to detect $\mathrm{AD}$ by monitoring their concentrations and compositions in tear samples [76, 77]. Significant AD biomarkers could be obtained from sweat to monitor health conditions of patients [78]. Sweat, an epidermal bio-fluid, contains different biomolecules and/or electrolytes due to their passage under hydrostatic or osmotic pressure from blood or other body fluids [79-83]. It is seldom used as 


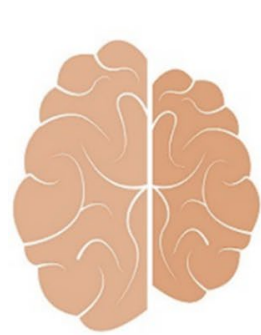

Alzheimer's disease

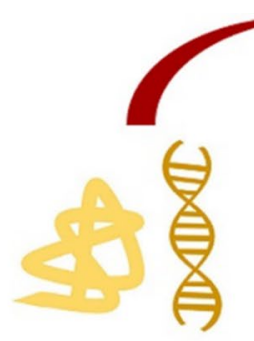

Biomarkers

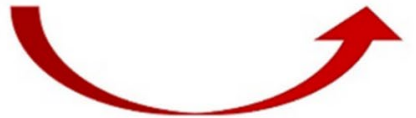

Fig. 1 Schematic representation of AD biosensor for the detection of various biomarkers present in different body fluids. Reprinted with permission from ref. [34]

a biosample for the diagnosis of AD due to a very dilute aqueous solution with very low concentrations of proteomics and biomolecules associated with AD. Thus, a biosensor with special ultrasensitive capacity is required to detect different biomarkers in sweat [84, 85]. Saliva is another potential biosamples containing different complex secretions and is considered to have direct relation with nervous system could show an important source of biomarkers for different types of nervous disorders [86, 87]. It contains various biomolecules passed from blood due to microfiltration or active transport. Therefore, saliva might be a promising source for the early and accurate detection of AD biomarkers [88, 89]. Primarily, t-tau and $\mathrm{p}$-tau are studied for the diagnosis of AD but another significant biomarker acetylecholinsterase, a type-B carboxylesterase enzyme is also studied as remarkable $\mathrm{AD}$ biomarkers which is associated with low concentration in $\mathrm{AD}$ patients [90]. Additionally, brain shows the presence of lactoferrin which substantially increases in $\mathrm{AD}$ patients. It is also correlated with the $\mathrm{AD}$ pathogenesis
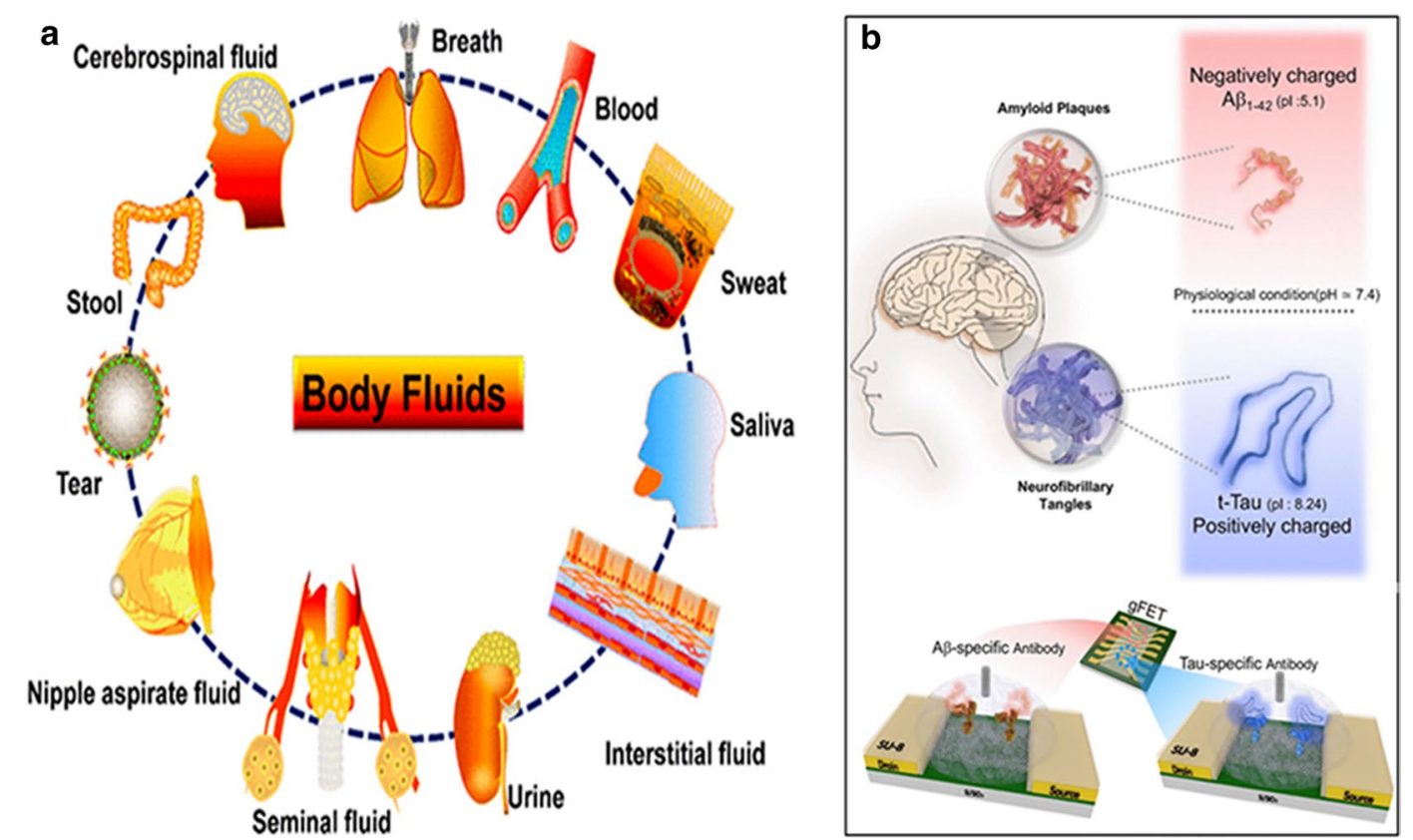

Fig. 2 Body fluids and AD biomarkers sensing technique: a Sources of different biosamples from human body. Reprinted with permission from ref. [19], and $\mathbf{b}$ Multiplex detection of A 42 peptide and t-Tau protein using graphene-based field effect transistor (gFET) biosensor. Reprinted with permission from ref. [67] 
because of the direct relation with microgila of brain, amyloid beta plaques, and NFT of patients [91, 92]. Although, there are various AD related biomolecules in secretions of salivary glands, the conclusiveness of the results is still limited due to the lack of proper and sufficient standardization [93]. Similarly, the nasal secretions and olfactory fluids might also be considered as the promising non-invasive biosamples for the early detection of AD biomarkers [94-96].

AD-related biomarkers can be incorporated for diagnosing early onset and progression of AD. Tau or T-proteins are a group of six highly soluble protein isoforms with lengths ranging from 352 to 441 amino acids. They are produced by alternative splicing of microtubuleassociated protein tau (MAPT), a heat-stable protein [97, 98]. Neurons of the central nervous system (CNS) are major sources of tau proteins [99]. A number of phosphorylation sites are present on tau protein. They are used to control the binding capacity of tau protein with different microtubule structures [97]. There is a dynamic equilibrium between phosphorylation and dephosphorylation of tau protein within the cell body [100]. Initially, dephosphorylated tau protein shows extensive associated forms of microtubules. With the initiation of phosphorylation, it begins to disassemble to form microtubule units [101]. Pathological hallmarks in the brain show the presence of excessive hyperphosphorylation of tau which forms insoluble neurofibrillary tangles (NFTs) and results in synaptic dysfunctions and neural cell damage [102]. The hyperphosphorylated form of tau is an insoluble intra-neuronal collection of proteins. This is the major element that forms NFTs. It is regarded as a key feature of AD [103].

Serial cleavage of APP results in the formation of A $\beta$. During cleavage, it produces peptides with chain lengths of 36 to 43 amino acids. A $\beta$-peptide with aggregated fibrillary networks of plaques is considered the major pathological marker for $\mathrm{AD}$. These plaques contain $\mathrm{A} \beta$ protein as a major component. Peptides having 40 and 42 amino acid units are indicated as $A \beta 40$ and $A \beta 42$, respectively [104]. Due to the tendency of higher aggregation, longer amyloid peptide (i.e. A $\beta 42$ ) undergoes oligomerization to produce soluble dimers or higher-order oligomers [105]. Continued aggregation of higher-order oligomers forms $A \beta$ fibrils. This is considered as a key factor for neurotoxicity caused by the production of toxic amyloid plaques, ultimately leading to neuronal cell death [106-108]. According to the amyloid hypothesis, $A \beta$ is regarded as a promising biomarker for AD $[109,110]$.

Apolipoprotein E (ApoE) is a polymorphic allele and the main genetic indicator of $\mathrm{AD}$. ApoE is an important cholesterol carrier that supports lipid transport and repairs brain injury. The presence of ApoE $\varepsilon 4$ alleles in bio-fluids is strictly associated with genetic risk factors involved in the emergence of cerebral amyloid angiopathy and age-related cognitive impairments that cause late onset of $\mathrm{AD}$ [111]. ApoE joins with a number of receptors on the cell surface to deliver lipids and hydrophobic A $\beta$-peptides, thus introducing toxicity, causing synaptic dysfunction, and resulting in the deterioration or death of neurons that finally leads to $\mathrm{AD}$. It induces the risk of appearance of $\beta$-amyloid senile plaques and neuritic plaques. Therefore, ApoE $\varepsilon 4$ alleles are considered as important indicators for the detection and prognosis of $\mathrm{AD}$.

Along with aforementioned biomarkers, other biomarkers of different categories, including genetic biomarkers, neuroimaging biomarkers, clinical biomarkers, and biochemical biomarkers, have been reported. For example, $A \beta$ peptide-derived diffusion ligands (ADDLs) [112], APP [113], BACE1 [114], $\alpha-1$-antitrypsin (AAT) [115], Alzheimer-associated neuronal thread protein (AD7c-NTP) [116], and NFL [117] are some significant $\mathrm{AD}$ biomarkers that have attracted tremendous research interest. Some biomolecules such as transthyretin [118], retinol-binding protein (RBP), $\beta 2$-microglobulin [119], ApoA1 (apolipoprotein A1) [120, 121], granin-like neuroendocrine precursor [122], pigment epitheliumderived factor (PEDF) [123], and haptoglobin [124] are also associated with clinical diagnosis of $\mathrm{AD}[125,126]$.

\section{CSF-based small biosensors}

AD biomarkers from CSF sample could offer reliable pathological evidence to diagnose $\mathrm{AD}$ prior to the onset of pathological hallmarks. The first measurement of $A \beta$ peptides from CSF was recorded by Tamaoka et al. in 1999 [127] and later in 2001. The t-tau protein was also determined in a CSF sample from a patient with Down's Syndrome (DS) [128]. A reverse relationship in the concentration of $A \beta 42$ peptides against $t$-tau and $p$-tau181 proteins indicates specific pathological conditions of $\mathrm{AD}$ patients compared to mild cognitive impairment (MCI) patients and normal controls. For example, decreased concentration of $A \beta$ peptide and increased concentration of tau proteins in CSF samples are associated with amyloidosis and the risk of AD progression. Clinical reports have shown the presence of low concentration of $A \beta 42$ but high concentrations of $t$-tau and p-tau in biosamples of AD patients than normal controls. These unusual proportions of biomarkers in CSF samples indicate the development of $A \beta$ plaques that can ultimately result in neuronal damage, neural degeneration, and formation of neocortical neurofibrillary tangles [129]. An increased level of NFL chain in CSF has been reported to be correlated with the appearance 
of AD [130]. Recently, Kang et al. developed the AuNPs loaded sensor platform to apply the localized surface plasmon resonance (LSPR) technique to detect Apolipoprotein (ApoE4) [131]. Table 1 shows results of comparison of analytical performances of different types of femto-, nano-, and micro-biosensors used to detect AD biomarkers from CSF samples.

\section{Femto-biosensors to detect CSF-based biomarkers}

Femto-level detection of biomarkers is required to facilitate the diagnosis of $\mathrm{AD}$ when concentrations of biomarkers are very low in biosamples. $\mathrm{Li}$ et al. have fabricated a magnetic nitrogen-doped graphene (MNG) immobilized with anti-A $\beta$ antibody (MNG$\mathrm{A} \beta \mathrm{ab}$ )-modified $\mathrm{Au}$ electrode. They used cyclic voltammetry (CV) and differential pulse voltammetry (DPV) techniques for the electrochemical measurements. Such MNG-Aßab-modified AuSPE biosensor was highly effective for the detection of $A \beta 42$ peptide with a linear range of $5000 \mathrm{fg} / \mathrm{mL}$ to $800 \mathrm{pg} / \mathrm{mL}$ and a limit of detection (LOD) of $5000 \mathrm{fg} / \mathrm{mL}$ [132]. Threedimensional zinc oxalate-metal organic frameworks $\mathrm{Ru}(\text { bpy })_{3}{ }^{2+} /$ Zinc oxalate 3D MOFs have been fabricated for femto molar detection of $\mathrm{A} \beta 42$ peptide from artificial CSF (aCSF) and BSA solutions using electrochemical impedance spectroscopy (EIS) technique, with a linear range of detection from $100 \mathrm{fg} / \mathrm{mL}$ to 50 $\mathrm{ng} / \mathrm{mL}$ and an LOD of $13.8 \mathrm{fg} / \mathrm{mL}$ [133]. Furthermore, an ultrasensitive electrochemical biosensor with cellular prion protein $\left(\mathrm{PrP}^{\mathrm{C}}\right)$ bio-receptor combined with poly(thiophene-3-acetic acid) as a transducer has been fabricated for the detection of amyloid beta oligomer $(A \beta O)$ using EIS technique as shown in Fig. 3. Qin et al. utilized mice brain-extracted CSF and obtained a wide range of detection within a subfemtomolar scale of $10^{-8}$ to $10^{4} \mathrm{nM}$ and an LOD of $10^{-2} \mathrm{fM}$ [134]. Thus, femto-biosensors using CSF samples are very significant for the detection of ultralow concentration of $\mathrm{AD}$ biomarkers for early diagnosis of diseases.

\section{Nano-biosensors to detect CSF-based biomarkers}

Majority of $\mathrm{AD}$ biomarkers are detected in the nanoscale range. With improved technologies, some researchers have developed a wide range of biosensors for nanoscale detection of AD biomarkers. A surfaceenhanced Raman scattering (SERS) biosensor platform has been fabricated by Zhang et al. using Raman dyecoated polyA aptamer-AuNPs (PAapt-AuNPs) and SERS technique for the detection of $A \beta 42$ oligomers and tau protein with a wide linear range of detection $1 \times 10^{-1}$ to $1 \times 10^{4} \mathrm{nM}$ and an LOD of $3.7 \times 10^{-2}$ $\mathrm{nM}$ for $\mathrm{A} \beta 42$ and $4.2 \times 10^{-4} \mathrm{pM}$ for tau protein [135]. Localized surface plasmon resonance (LSPR) technique was utilized for the detection of amyloid beta (1-42) peptide as shown in Fig. 4, using an optical sensor fabricated using ligand-exchange AuNPs deposited on polyethylene terephthalate (PET) film by Langmuir-Blodgett (LB) method. This sensor detected $A \beta 42$ peptide with the limit of detection as $0.001 \mathrm{ng} / \mathrm{mL}$ [138]. Similarly, an antibody immobilized graphene oxide biosensor conjugated with dendrimer- $\mathrm{PbS} / \mathrm{CdS}$ electrochemical nano-platform has been prepared for the detection of tau protein. This immunosensor used DPV and electrochemical impedance spectrometry (EIS) techniques and established a linear range of detection as $0.5-15.1 \mathrm{nM}$ with an LOD of $0.15 \mathrm{nM}$ [136]. Yu et al. have designed a single ratio-metric electrochemical biosensor of 2,2'-azinobis-3-ethylbenzothiazoline-6-sulphonate (ABTS) and poly(diallyldimethylammonium chloride) (PDDA) bi-functionalized single-walled carbon nanotubes (SWNTs) composite to detect A 442 from the hippocampus of AD rats. This biosensor applied DPV method to detect $A \beta 42$ with an LOD of $0.5 \mathrm{ng} / \mathrm{mL}$ and a linear range of detection as $1 \mathrm{ng} / \mathrm{mL}$ to $3.08 \mu \mathrm{g} / \mathrm{mL}$ [137]. Qin et al. have prepared cellular prion protein and poly(pyrrole-2-carboxylic acid) immobilized electrode to monitor amyloid beta oligomers for early diagnosis of AD biomarkers. They used mice CSF samples for the detection of oligomers using cyclic voltammetry $(\mathrm{CV})$ and EIS technique, showing a limit of detection of $10^{-7} \mathrm{nM}$ [139]. A $\beta$ oligomers (A $\beta \mathrm{Os}$ ) could be detected from artificial CSF samples using a graphene oxide-based biosensor platform for selective capturing of target oligomers with a fluorescence method. This tool was successful for the detection of oligomers in a wide linear range of concentrations from $10 \mathrm{nM}$ to 2 $\mu \mathrm{M}$ with a limit of detection of $1 \mathrm{nM}$ [140].

\section{Micro-biosensors to detect CSF-based biomarkers}

For micro-scale detection of AD biomarkers, a researcher group has fabricated anti-tau protein modified Au disk electrode for the detection of tau protein from CSF biosamples using CV and EIS technique. They observed a linear range of detection of 
Table 1 Analytical performances of CSF-based biosensors

\begin{tabular}{|c|c|c|c|c|c|c|}
\hline \multicolumn{2}{|l|}{ Sensor type } & \multirow{2}{*}{$\begin{array}{l}\text { Target } \\
\text { A } \beta 42\end{array}$} & \multirow{2}{*}{$\begin{array}{l}\text { Analytical method } \\
\text { Cyclic voltammetry (CV) } \\
\text { and differential potential } \\
\text { voltammetry (DPV) }\end{array}$} & \multirow{2}{*}{$\begin{array}{l}\text { Detection range } \\
5000 \mathrm{fg} / \mathrm{mL}- \\
800 \mathrm{pg} / \mathrm{mL}\end{array}$} & \multirow{2}{*}{$\begin{array}{l}\text { Limit of detection } \\
5000 \mathrm{fg} / \mathrm{mL}\end{array}$} & \multirow{2}{*}{$\frac{\text { Refs. }}{\text { [132] }}$} \\
\hline Femto- sensors & $\begin{array}{l}\text { Magnetic nitrogen-doped } \\
\text { graphene (MNG) immo- } \\
\text { bilized with } A \beta \text { antibody } \\
\text { (MNG-Aßab) on Au } \\
\text { electrode }\end{array}$ & & & & & \\
\hline & $\begin{array}{l}\text { Ru(bpy })_{3}{ }^{2+} / \text { Zinc oxalate } \\
\text { metal-organic framework } \\
\text { (MOF) }\end{array}$ & $A \beta$ & $\begin{array}{l}\text { Electrochemical imped- } \\
\text { ance spectroscopy (EIS) }\end{array}$ & $100 \mathrm{fg} / \mathrm{mL}-50 \mathrm{ng} / \mathrm{mL}$ & $13.8 \mathrm{fg} / \mathrm{mL}$ & [133] \\
\hline & $\begin{array}{l}\text { Cellular prion protein }\left(\mathrm{PrP}^{\mathrm{C}}\right) \\
\text { with a layer of poly( } 3,4- \\
\text { ethylene dioxythiophene } \\
\text { (PEDOT) embedded } \\
\text { AuNPs }\end{array}$ & $\mathrm{A} \beta \mathrm{O}$ & EIS & $0.1 \mathrm{fM}-10^{4} \mathrm{nM}$ & $0.1 \mathrm{fM}$ & [134] \\
\hline \multirow[t]{6}{*}{$\begin{array}{l}\text { Nano- } \\
\text { sensors }\end{array}$} & $\begin{array}{l}\text { Raman dye-coated polyA } \\
\text { aptamer-AuNPs (PAapt- } \\
\text { AuNPs) }\end{array}$ & $\begin{array}{l}\text { A } \beta 42 \text { and } \\
\text { Tau }\end{array}$ & $\begin{array}{l}\text { Surface-enhanced Raman } \\
\text { scattering } \\
\text { (SERS) }\end{array}$ & $1 \times 10^{-1}-1 \times 10^{4} \mathrm{nM}$ & $\begin{array}{l}3.7 \times 10^{-2} \mathrm{nM} \\
\text { and } \\
4.2 \times 10^{-4} \mathrm{pM}\end{array}$ & [135] \\
\hline & $\begin{array}{l}\text { Anti-Tau modified } \\
\text { screen printed carbon } \\
\text { electrode (SPCE) with } \\
\text { graphene oxide (GO) and } \\
\text { amine functionalized } \\
\text { trimethylolpropane tris } \\
\text { poly(propylleneglycol) } \\
\text { (pPG) }\end{array}$ & Tau & $\begin{array}{l}\text { DPV and } \\
\text { EIS }\end{array}$ & $0.5-15.1 \mathrm{nM}$ & $0.15 \mathrm{nM}$ & [136] \\
\hline & $\begin{array}{l}\text { 2,2'-azino-bis(3-ethyl- } \\
\text { enebenzothiazoline- } \\
\text { 6-sulfonic acid-polydial- } \\
\text { lylmethylammonium } \\
\text { chloride (ABTS-PDDA) } \\
\text { bi-functionalized with } \\
\text { SWCNTs loaded with } \\
\text { neurokinin B }\end{array}$ & $A \beta 42$ & DPV & $1 \mathrm{ng}-0.38 \mu \mathrm{g} / \mathrm{mL}$ & $0.5 \mathrm{ng} / \mathrm{mL}$ & [137] \\
\hline & $\begin{array}{l}\text { AuNPs deposited on poly- } \\
\text { ethylene terephthalate } \\
\text { (PET) film by Langmuir- } \\
\text { Blodgett (LB) method }\end{array}$ & $\mathrm{A} \beta 42$ & $\begin{array}{l}\text { Localized surface plasmon } \\
\text { resonance (LSPR) }\end{array}$ & - & $0.001 \mathrm{ng} / \mathrm{mL}$ & [138] \\
\hline & $\begin{array}{l}\text { Au disc coated with } \\
\text { polypyrrol-2-COOH } \\
\text { film immobilized } \\
\mathrm{NH}_{2} \text {-terminated PrPc }\end{array}$ & $A \beta O$ & EIS & $10^{-7}-0 \mathrm{nM}$ & $10^{-7} \mathrm{nM}$ & [139] \\
\hline & $\begin{array}{l}\text { Graphene oxide-based } \\
\text { platform immobilized } \\
\text { with } A \beta O \text { antibody }\end{array}$ & $A \beta O$ & Fluorescence & $10 \mathrm{nM}-2 \mu \mathrm{M}$ & $1 \mathrm{nM}$ & [140] \\
\hline \multirow[t]{4}{*}{ Micro-sensors } & $\begin{array}{l}\text { Tau protein-based Au disk } \\
\text { electrode }\end{array}$ & Tau441 & $\begin{array}{l}\text { CV and } \\
\text { EIS }\end{array}$ & $0.1-1.0 \mu \mathrm{M}$ & $0.2 \mu \mathrm{M}$ & [141] \\
\hline & $\begin{array}{l}\text { AD7c-NTP antibodies } \\
\text { immobilized sandwich } \\
\text { immunoassay }\end{array}$ & AD7c-NTP & ELISA & - & $0.0092 \mu \mathrm{g} / \mathrm{mL}$ & [142] \\
\hline & $\begin{array}{l}96 \text { well microtiter plates } \\
\text { coated with monoclonal } \\
\text { antibody (N314) }\end{array}$ & AD7c-NPT & ELISA & $3 \times 10^{-5}-5 \times 10^{-5} \mu \mathrm{g} / \mathrm{mL}$ & $0.002 \mu \mathrm{g} / \mathrm{mL}$ & [143] \\
\hline & $\begin{array}{l}\text { Reduced graphene oxide } \\
\text { (RGO)-based enzyme- } \\
\text { modified field-effect } \\
\text { transistor (RGO-EnFET) }\end{array}$ & Acetylcholine (ACh) & $\begin{array}{l}\text { Electrical conductance } \\
\text { measurement }\end{array}$ & $1 \mu \mathrm{M}-10 \mathrm{mM}$ & $1 \mu \mathrm{M}$ & [144] \\
\hline
\end{tabular}

$0.1-1.0 \mu \mathrm{M}$ and an LOD of $0.2 \mu \mathrm{M}$ [141]. Additionally, the measurement of AD7c-NTP showed diagnostic features of AD patients. A group of researchers have used ELISA technique-based biosensors for the detection of
AD7c-NTP biomarker from postmortem human CSF samples. The device could successfully measure levels of the AD7c-NTP biomarker with a limit of detection of $0.0092 \mu \mathrm{g} / \mathrm{mL}$ in Alzheimer's patients, higher than that of normal controls $(0.0016 \mu \mathrm{g} / \mathrm{mL})$ [142]. Ghanbari 


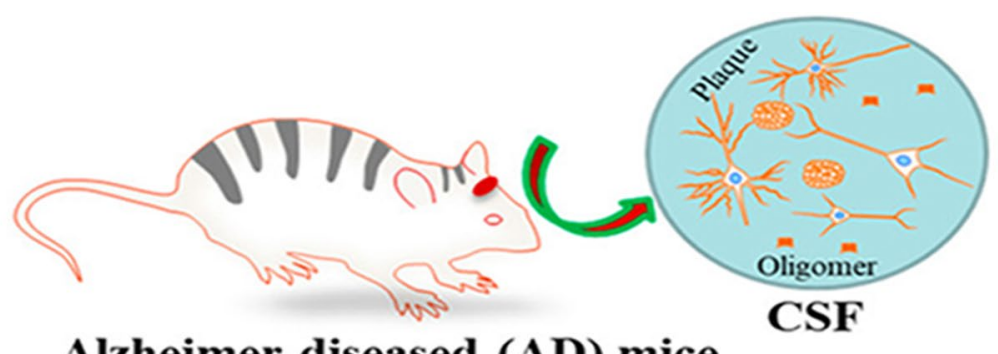

Alzheimer diseased (AD) mice
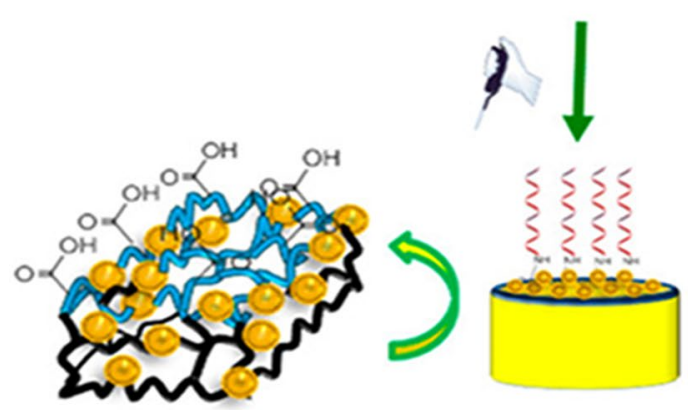

Prepared electrode
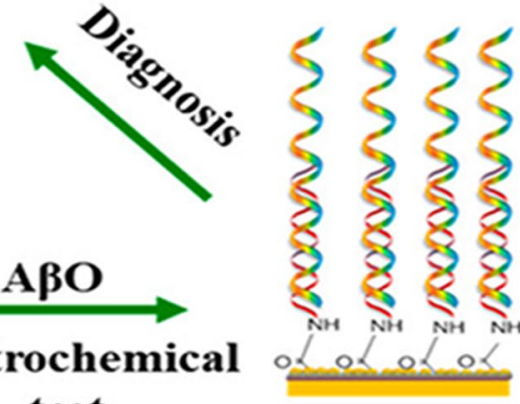

test

Fig. 3 Ultrasensitive detection of amyloid-beta-oligomers in mice CSF using a poly(3,4-ethylene dioxythiophene) (PEDOT)-embedded Au nanoelectrode. Reprinted with permission from ref. [134]

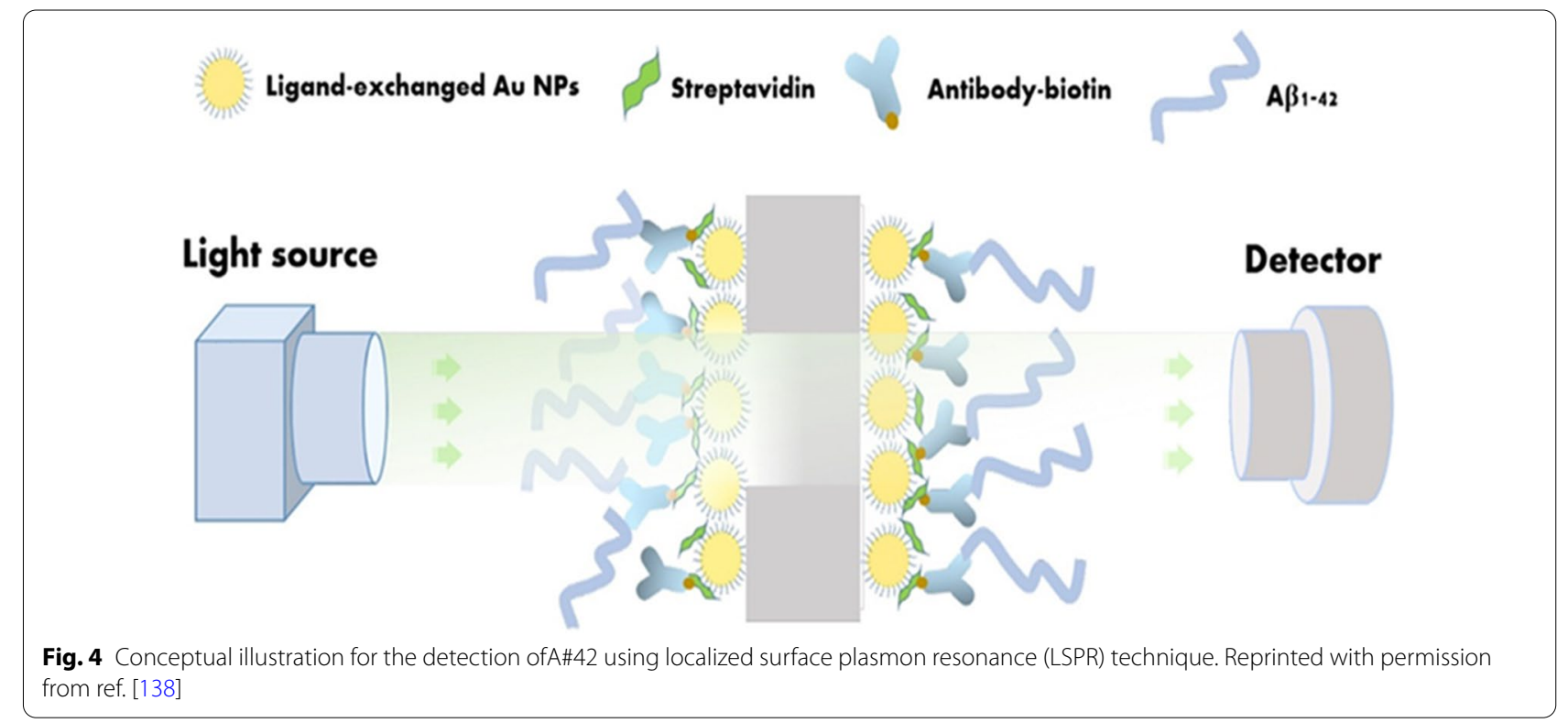

et al. have designed a sandwich-type enzyme immunoassay to measure levels of AD7c-NTP biomarker in CSF samples of AD patients. This sandwich assay was able to detect the biomarker at a linear range of detection of $3 \times 10^{-5}$ to $5 \times 10^{-5} \mu \mathrm{g} / \mathrm{mL}$ with a limit of detection of $0.002 \mu \mathrm{g} / \mathrm{mL}$ [143]. CSF is supposed to be a typical biosample for leukocytes trafficking into the CNS
[145]. An enzyme-modified graphene-based transistor biosensor platform has been fabricated to detect acetylcholine (Ach) and monitor drug delivery. This transistor biosensor could measure Ach in a linear range of $1 \mu \mathrm{M}$ to $10 \mathrm{mM}$ using the electrical conductance method [144]. 


\section{Blood-based small biosensors}

Blood is a popular biosample for in vitro diagnosis of diverse diseases. Although the blood-brain-barrier (BBB) separates the blood stream from the CSF, brain-derived proteins in a low quantity are selectively exchanged between these two bio-fluids. For this reason, blood sample can also be used exclusively for studying brainrelated pathologies. In contrast to CSF, blood shows more complex compositions because of the presence of different biomolecules such as glucose, lipids, creatinine, hormones, antibodies, proteins, and cytokines. These interfering elements hinder biomarker detection using traditional detection platforms. Furthermore, low concentrations of brain-associated biomarkers in blood samples demand highly selective and sensitive tools for biomarker detection. Different blood-based biosensors with their detection targets, ranges of detection, and limits of detection are summarized in Table 2.

\section{Femto-biosensors to detect blood-based biomarkers}

Electrochemically reduced graphene oxide (ERGO) and $\mathrm{Au}$ nanowires (AuNWs) have been used for the fabrication of screen printed carbon electrode (SPCE) with doxorubicin (Dox) and applied for the early detection of serum microRNA137 by CV and EIS techniques. Its linear range of detection was 5.0-750.0 fM and its LOD was $1.7 \mathrm{fM}$ [33]. Kim et al. have successfully designed a closely packed and highly aligned CNT sensor array for multiplexed sensing of core biomarkers as shown in Fig. 5. This was used to measure levels of AD biomarkers using fluorescence and resistance measurement techniques, showing LOD values of $2.45,2.72,2.20$, and $2.13 \mathrm{fM} / \mathrm{mL}$ for $\mathrm{t}$-tau, p-tau181, $\mathrm{A} \beta 42$, and $A \beta 40$, respectively [146]. An electrochemical immunoassay has been developed by Diba et al. from sandwich immunoassay fabricated with an antibody coated on a monolayer obtained by mixing 3-mercaptopropionic acid (MPA) and thiol modified polyethylene glycol (PEG-SH) localized on AuNPs over the screen printed carbon electrode (SPCE). Electrochemical impedance spectroscopy (EIS) has been applied for the detection of $A \beta 42$ with an LOD of $100 \mathrm{fM}$ and a linear range of detection from $0.1 \mathrm{fM}$ to $25 \mathrm{fM}$ [147]. Demeritte et al. have designed a label-free hybrid graphene oxide platform for simultaneous detection of $\mathrm{A} \beta 42$ and tau protein using surface enhanced Raman spectroscopy (SERS) technique. This biosensor device showed an LOD value of $100 \mathrm{fg} / \mathrm{mL}$ for $\mathrm{A} \beta 42$ and tau protein [148]. A shape code type AuNPs nanoplasmonic sensor was used for the detection of AD biomarkers from mimicked blood sample using localized surface plasmon resonance (LSPR). This sensor showed the LOD for $\mathrm{A} \beta 40, \mathrm{~A} \beta 42$, and tau protein as $34.9 \mathrm{fM}, 26 \mathrm{fM}$, and $23.6 \mathrm{fM}$ respectively [158].
Similarly, Yoo et al. have designed a blood-based ultrasensitive label-free platform of integrated microelectrode (IME) sensor for the detection of $A \beta$-peptide using the EIS technique. It showed a detection range from $100 \mathrm{fg} /$ $\mathrm{mL}$ to $1 \mathrm{ng} / \mathrm{mL}$ [149]. Further, MWCNTs, reduced graphene oxide (rGO), and chitosan (CS) have been applied for biosensor fabrication to detect tau441 protein with a linear range of detection of $0.5-80 \mathrm{fM}$ and an LOD of $0.46 \mathrm{fM}$ using the DVP technique [150]. Kim et al. have prepared an ultrasensitive biosensor using $\mathrm{BiVO}_{4}$-based photoelectrochemical (PEC) platform by incorporating molybdenum (Mo) dopant and iron oxyhydroxide $(\mathrm{FeOOH})$ layer on the photoelectrode with horseradish peroxidase (HRP) as a signal amplifier to trigger the oxidation of 3,3'-diaminobenzidine (DAB) [151]. They used the EIS technique to measure tau in blood plasma and found an LOD of $1.59 \mathrm{fM}$.

Another biomarker ADAM10 can be measured with a disposable microfluidic platform using poly(diallyldimethyl ammonium chloride) (PDDA) and AuNPs bilayer electrode from human blood plasma. The CV technique has been applied for the detection of biomarker, showing a detection range of 5.6$1.38 \times 10^{3} \mathrm{fg} / \mathrm{mL}$ and an LOD of $0.35 \mathrm{fg} / \mathrm{mL}$ [152]. Similarly, Kim et al. have prepared a DNA aptamer/ antibody sandwich assay for tau381 detection using a multichannel surface plasmon resonance (SPR) platform. This sensor could detect tau381 with an LOD of $10 \mathrm{fM}$ and a detection range of 2 to $80 \mathrm{pM}$ using the SPR technique [153]. Au-functionalized monolayer of 11-mercaptoundecanoic acid (MUA) coupled with tau antibody has been used for an effective detection of tau381 by the SPR technique, showing an LOD of $~ 39$ fM [154]. Luminol-based immunosensor with ceria doped $\mathrm{ZnO}$ nanoflower has been used for $\mathrm{A} \beta$-peptide detection from PBS and human serum at an ultralow LOD of $52 \mathrm{fg} / \mathrm{mL}$ and a wide detection range from $80 \mathrm{fg} / \mathrm{mL}$ to $100 \mathrm{ng} / \mathrm{mL}$ using an electrochemiluminescence technique [155]. A nanoplasmonic biosensor using a chaotic agent was applied for the ultrasensitive detection of $\mathrm{AD}$ biomarkers from undiluted human plasma. This biosensor was able to detect the tau protein within the concentration range of 102 to $108 \mathrm{fM}$ with the minimum detectable concentration as 100 $\mathrm{fM}$ using Localized surface plasmon resonance (LSPR) technique [163]. Additionally, tau-381 protein can be detected with cysteamine-stabilized AuNPs as signal amplifier employing DPV technique within a range of detection from 500 to $10^{4} \mathrm{fM}$ and an LOD of $420 \mathrm{fM}$ [156]. Anti-tau modified AuNPs have been functionalized with magnetic nanoparticles and used to detect tau381 by SERS technique. The device showed a linear range of detection of $25 \mathrm{fM}$ to $500 \mathrm{nM}$ with an 


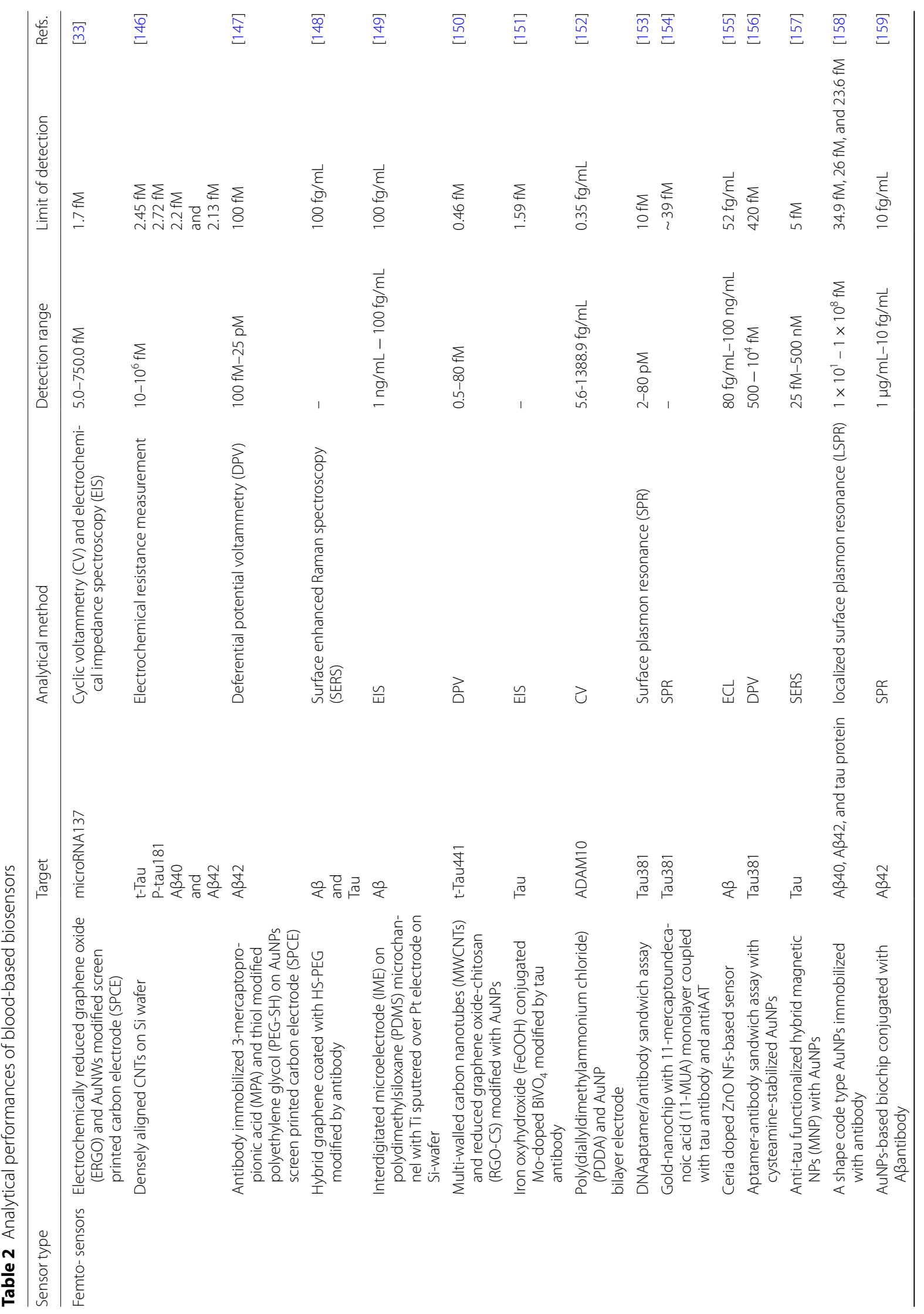




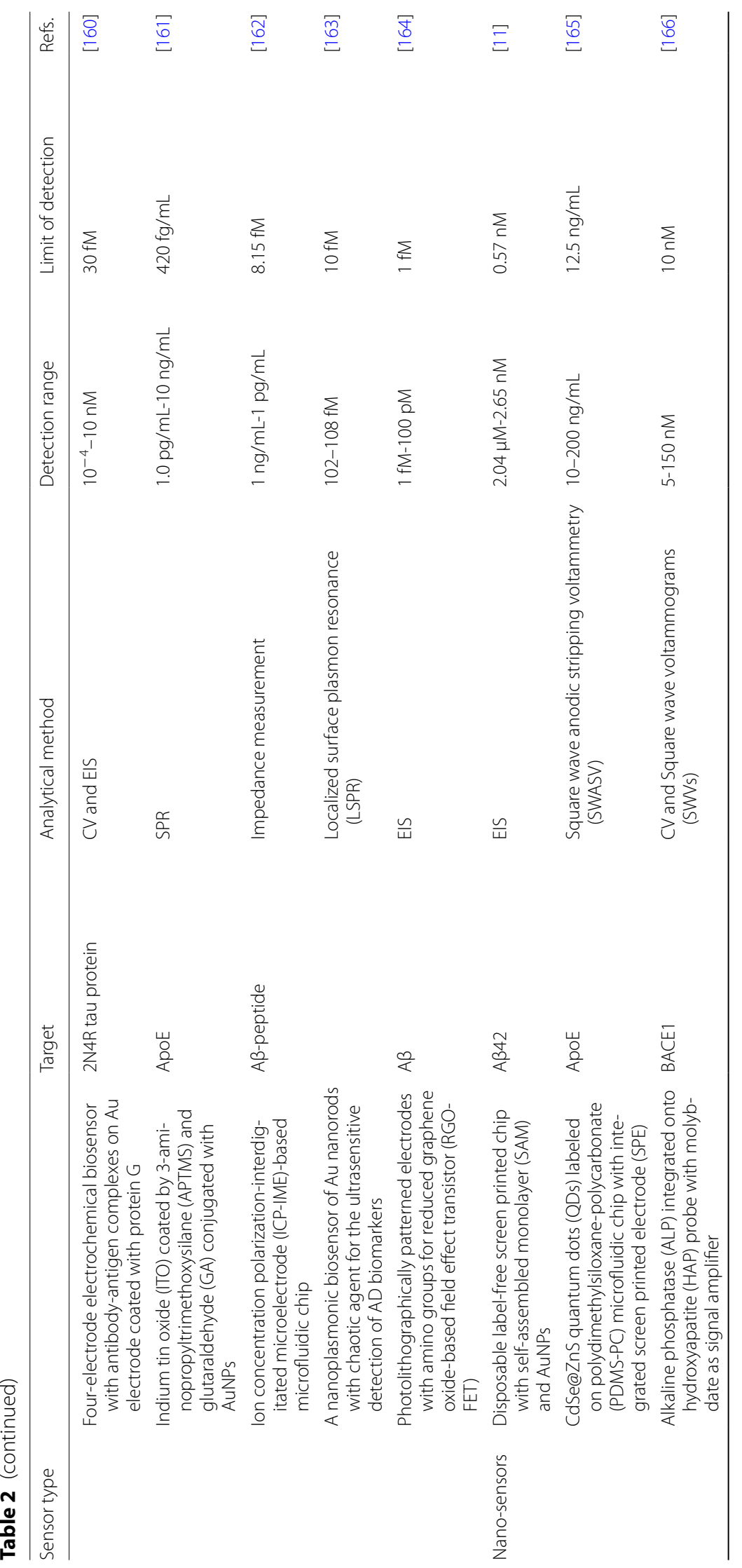




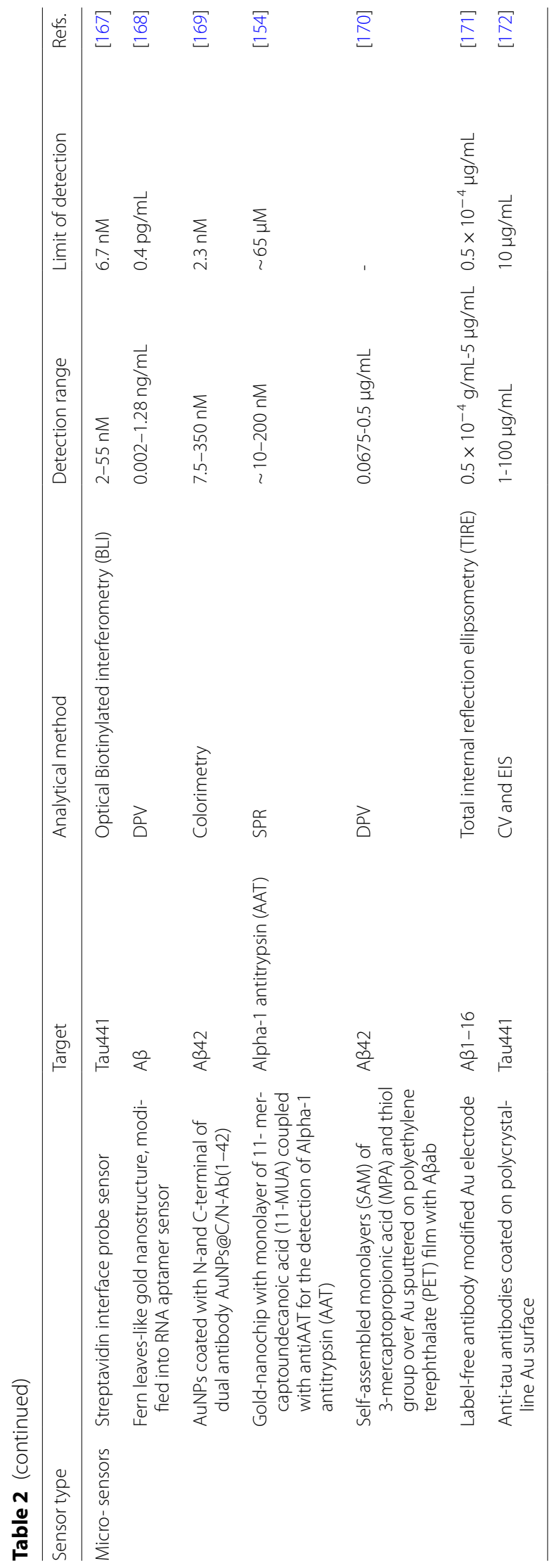




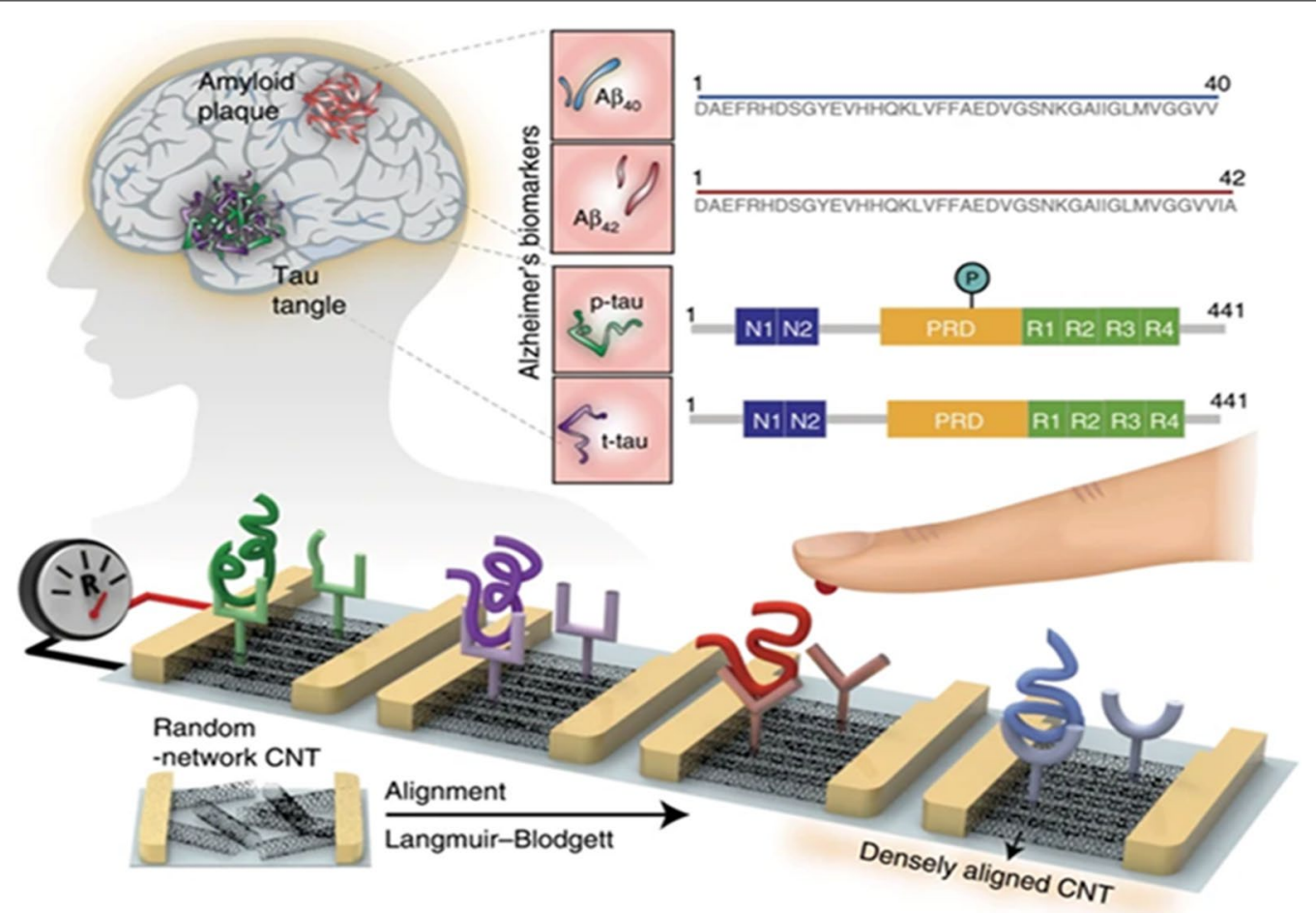

Fig. 5 Thin film biosensor with densely aligned SWNTs for the multiplex detection of Aß-peptide from blood. Reprinted with permission from ref. [146]

LOD of $25 \mathrm{fM}$ [157]. Scanning tunneling microscopy (STM)-based biochip has been prepared with AuNPsA $\beta$ antibody conjugation for the detection of $A \beta 42$ within a concentration range of $1 \mu \mathrm{g} / \mathrm{mL}$ to $10 \mathrm{fg} /$ $\mathrm{mL}$ and an LOD of $10 \mathrm{fg} / \mathrm{mL}$ using the SPR technique [159]. A biosensor with four-electrode system has also been used for the detection of serum 2N4R tau protein applying $\mathrm{CV}$ and EIS techniques and obtained a linear range of detection of $10^{-4}-10 \mathrm{nM}$ and an LOD of $30 \mathrm{fM} \mathrm{[160].} \mathrm{Ren} \mathrm{et} \mathrm{al.} \mathrm{have} \mathrm{designed} \mathrm{a} \mathrm{colorimetric}$ immunosensor using indium tin oxide (ITO) modified by 3-aminopropyltrimethoxysilane (APTMS) and glutaraldehyde (GA) conjugated with AuNPs-antibody using SPR and colorimetric technique for the detection of ApoE biomarker. The device could detect ApoE within a linear range of $1.0 \mathrm{pg} / \mathrm{mL}$ to $10 \mathrm{ng} / \mathrm{mL}$ and an LOD of $420 \mathrm{fg} / \mathrm{mL}$ [161]. Ion concentration polarization-interdigitated microelectrode (ICP-IME)-based microfluidic sensor has been prepared by Yoo et al. to measure A $\beta$-peptide using impedance measurement technique. It showed a linear detection range of $1 \mathrm{ng} / \mathrm{mL}-1 \mathrm{pg} / \mathrm{mL}$ and an LOD of $8.15 \mathrm{fM}$ [162]. Kurkina et al. have used photo-lithographically patterned electrodes with amino groups to produce rGO-FET immunosensor for the detection of $A \beta$ peptide from serum with an LOD of 1
$\mathrm{fM}$ and a linear range of $1 \mathrm{fM}$ to $100 \mathrm{pM}$ with the help of the EIS technique [164].

\section{Nano-biosensors to detect blood-based biomarkers}

A label-free impedimetric immunosensor on a carbon disposable electrochemical screen printed chip has been developed using self-assembled monolayer (SAM) and AuNPs for the measurement of $A \beta 42$ [11]. The attractive disposable carbon chip could measure amyloid beta within a linear range of detection of $2.04 \mu \mathrm{M}$ to $2.65 \mathrm{nM}$ and an LOD of $0.57 \mathrm{nM}$. An on-chip magneto-immunoassay has been fabricated using cadmium selenide/zinc sulfide QDs. An immunocomplex device has been made with tosylated magnetic beads as a pre-concentration chamber on a polydimethylsiloxane (PDMS)-polycarbonate (PC) microfluidic chip with integrated SPE for the detection of biomarker ApoE using a square wave anodic striping voltammetry (SWASV) technique. The microchip could effectively measure the level of ApoE with a detection range of $10-200 \mathrm{ng} / \mathrm{mL}$ and an LOD as $12.5 \mathrm{ng} / \mathrm{mL}$ [165]. Qu et al. have designed alkaline phosphatase (ALP) with a redox-generating hydroxyapatite (HAP) probe for dual signal amplification and amyloid beta antibody immobilization on the surface of an electrode [166]. This sensing probe could detect BACE1 protease in human serum with a linear range of detection of 
5-150 nM and an LOD of $10 \mathrm{nM}$ with CVs and SWVs. Similarly, a simple bio-chip with a very easy handling process has been designed as a dip-and-read label-free optical aptasensor based on a biolayer interferometry (BLI) technique. It was developed for the detection of tau441 protein from buffer and serum solutions with a limit of detection of $6.7 \mathrm{nM}$ and a linear range of detection of $2 \mathrm{nM}$ to $55 \mathrm{nM}$ [167]. This aptasensor was successfully developed with the BLI detection technique. Negahdary et al. have reported a linear range of 0.002 to $1.28 \mathrm{ng} / \mathrm{mL}$ and an LOD of $0.4 \mathrm{pg} / \mathrm{mL}$ for the detection of $A \beta 42$. They have designed an interesting fern leaveslike gold nanostructure this is modified for RNA aptamer binding with $A \beta$ that could be detected with a ferro/ ferricyanide redox marker using DPV technique [168]. Another study has reported a sandwich immunosensor for the detection of $\mathrm{A} \beta 42$ based on dual antibody-modified AuNPs with a colorimetric technique. AuNPs were successfully coated with $\mathrm{N}$ - and C-terminal of antibodies, resulting in an aggregate of AuNPs@C/N-Ab(1-42). This device detected $A \beta 42$ within a linear range of detection of $7.5 \mathrm{nM}$ to $350 \mathrm{nM}$ and an LOD of $2.3 \mathrm{nM}$ [169].

\section{Micro-biosensors to detect blood-based biomarkers}

The micro-level sensing method for in vitro determination of A 342 peptides was carried out using the DPV technique. The sensor was fabricated with self-assembled monolayers (SAM) using 3-mercaptopropionic acid (MPA) to immobilize the thiol group on a $50 \mathrm{~nm} \mathrm{Au}$ sputtered on polyethylene terephthalate (PET) substrate. The electrode was functionalized with $\mathrm{A} \beta$-antibody $(\mathrm{A} \beta$ ab) modified with 3-mercaptopropionic acid (MPA). It showed a linear range of detection of 0.0675 to $0.5 \mu \mathrm{g} /$ $\mathrm{mL}$ [170]. Sometimes, the detection of smaller and watersoluble amyloid beta peptide molecules (A $11-16)$ might be a step forward in the development of biosensors with cost effective and rapid test techniques. One study has reported the use of total internal reflection ellipsometry (TIRE) immunoassay with DE2 antibodies for the detection of small water soluble amyloid beta peptides (A $\beta 1-$ 16) [173]. Mustafa et al. have applied TIRE and quartz crystal microbalance (QCM) measurement techniques for the detection of A $\beta 1-16$ and reported an LOD of $0.5 \times 10^{-4} \mu \mathrm{g} / \mathrm{mL}$ and a wide-range of linear concentrations from $0.5 \times 10^{-4} \mu \mathrm{g} / \mathrm{mL}$ to $5 \mu \mathrm{g} / \mathrm{mL}$ using antibody modified Au electrode [171]. Similarly, another study has reported an electrochemical immunosensor with a wide range of detection of 1 to $100 \mu \mathrm{g} / \mathrm{mL}$ and an LOD of 10 $\mu \mathrm{g} / \mathrm{mL}$ for non-phosphorylated tau 441 protein using tauantibody coated on polycrystalline $\mathrm{Au}$ surfaces (Ab-Au) with CV and EIS techniques [172].

\section{Urine-based small biosensors}

Urine is a popular sample with an easy mode of collection to diagnose diverse diseases. Table 3 presents different urine-based biosensors used for the detection of AD target molecules. Unlike other biosamples, the use of urine for the detection of AD biomarkers involves simple and standard procedures. The detection of $\mathrm{AD}$ biomarkers can be easily performed based on creatinine concentration [174]. The level of glycine, a type of amino acid, is increased in urine samples collected from AD patients [175].

\section{Femto-biosensors to detect urine-based biomarkers}

Urine contains very significant AD biomarkers produced by oxidative degradation of DNA (i.e., 8-hydroxy-2'-deoxyguanosine or 8-OHdG). Zhang et al. have fabricated a highly sensitive fluorescence probe using a specific antibody to detect 8-OHdG with consecutive florescence labeling. The highly sensitive biosensor probe can detect 8-OHdG in urine samples collected from AD transgenic mice with an LOD of 0.18 fM using a capillary electrophoresis laser-induced fluorescence (CE-LIF) detection technique [176].

\section{Nano-biosensors to detect urine-based biomarkers}

Zengi et al. have reported the mean urinary level of 8 -OHdG is $115.7 \pm 50 \mathrm{nmol} / \mu \mathrm{mol}$ creatinine in $\mathrm{AD}$ patients and $9.28 \pm 2.23 \mathrm{nmol} / \mu \mathrm{mol}$ creatinine in the control group. They applied a high performance liquid chromatography-electrochemical detection (HPLCECD) technique for the measurement of 8-OHdG biomarker [42]. A group of researchers led by Zhang have evaluated AD7c-NTP, an AD biomarker present in urine, using an ELISA technique. They found that the level of AD7c-NTP was $0.48 \mathrm{ng} / \mathrm{mL}$ in a senior age population with lower cognitive function (LCF) and 0.25 $\mathrm{ng} / \mathrm{mL}$ in normal cognitive controls [17]. A $\beta$ peptide can be detected using polyvinylidene difluoride (PVDF) membrane incubated with primary antibody solution of human $A \beta$ monoclonal antibody [177]. This membrane sensor could detect amyloid biomarker with the help of western blotting technique. Its limit of detection was $0.04 \mathrm{ng} / \mathrm{mL}$. Ghanbari et al. have used a 96-well microtiter plate coated with monoclonal antibody (N3I4) immunoassay to prepare enzyme linked sandwich immunoassay (ELISA). They applied HPLC technique for the measurement of AD7c-NPT biomarker and found that its mean level was $2.5 \mathrm{ng} / \mathrm{mL}$ in urine samples of $\mathrm{AD}$ patients, higher than that $(0.8 \mathrm{ng} / \mathrm{mL})$ in the normal control group [178]. 
Table 3 Analytical performances of urine-based biosensors

\begin{tabular}{|c|c|c|c|c|c|c|}
\hline \multicolumn{2}{|c|}{ Sensor type } & \multirow{2}{*}{$\begin{array}{l}\text { Target } \\
\text { 8-OHdG }\end{array}$} & \multirow{2}{*}{$\begin{array}{l}\text { Analytical method } \\
\text { Capillary electrophoresis-laser- } \\
\text { induced fluorescence (CE-LIF) } \\
\text { detection }\end{array}$} & \multirow{2}{*}{$\begin{array}{l}\text { Detection } \\
\text { range }\end{array}$} & \multirow{2}{*}{$\begin{array}{l}\text { Limit of detection } \\
0.18 \mathrm{fM}\end{array}$} & \multirow{2}{*}{$\begin{array}{l}\text { Refs. } \\
{[176]}\end{array}$} \\
\hline $\begin{array}{l}\text { Femto- } \\
\text { sensors }\end{array}$ & $\begin{array}{l}\text { Fused silica column capillary with } \\
\text { total length } 42 \mathrm{~cm} \text { and effective } \\
\text { length } 30 \mathrm{~cm} \text { binding with anti- } \\
\text { 8-OHdG }\end{array}$ & & & & & \\
\hline \multirow[t]{4}{*}{$\begin{array}{l}\text { Nano- } \\
\text { sensors }\end{array}$} & $\begin{array}{l}\text { Solid phase extraction (SPE) in C18/ } \\
\text { OH column and HPLC in } 5 \mu \mathrm{mC} 18 \\
\text { HPLC with } 1 \mathrm{~mL} / \mathrm{min} \text { mobile phase } \\
\text { flow rate }\end{array}$ & $8-\mathrm{OHdG}$ & $\begin{array}{l}\text { High performance liquid chroma- } \\
\text { tography-electrochemical detec- } \\
\text { tion (HPLC-ECD) }\end{array}$ & $7.0-700 \mathrm{nM} / \mathrm{L}$ & $0.35 \mathrm{nM} / \mathrm{L}$ & {$[42]$} \\
\hline & $\begin{array}{l}\text { Antibody modified sandwich immu- } \\
\text { noassay }\end{array}$ & AD7c-NTP & ELISA & - & $0.48 \mathrm{ng} / \mathrm{mL}$ & {$[17]$} \\
\hline & $\begin{array}{l}\text { Polyvinylidene fluoride (PVDF) mem- } \\
\text { brane with monoclonal antibody }\end{array}$ & $A \beta$ & Western blots & - & $0.04 \mathrm{ng} / \mathrm{mL}$ & [177] \\
\hline & $\begin{array}{l}\text { 96-well microtiter plate coated with } \\
\text { monoclonal antibody (N314) }\end{array}$ & AD7c-NTP & HPLC & - & $2.5 \mathrm{ng} / \mathrm{mL}$ & {$[178]$} \\
\hline \multirow[t]{5}{*}{$\begin{array}{l}\text { Micro- } \\
\text { sensors }\end{array}$} & $\begin{array}{l}\text { Microtiter plate coated with bispe- } \\
\text { cific receptor antibody having } \\
\text { affinity for immunoglobulin G (lgG) } \\
\text { and urinary NTP }\end{array}$ & AD7c-NTP & $\begin{array}{l}\text { Enzyme-linked sandwich immuno- } \\
\text { assay (ELISA) }\end{array}$ & - & $26.8 \pm 9.4 \mu \mathrm{g} / \mathrm{mL}$ & [179] \\
\hline & $\begin{array}{l}\text { 32-well microtiter plates immunoas- } \\
\text { say }\end{array}$ & NTP & ELISA & $10-60 \mu \mathrm{g} / \mathrm{mL}$ & $10 \mu \mathrm{g} / \mathrm{mL}$ & [180] \\
\hline & $\begin{array}{l}\text { Rabbit immunoglobulin G (IgG) } \\
\text { coated immunosensor }\end{array}$ & AD7c-NTP & ELISA & - & $32.76 \pm 9.0 \mu \mathrm{g} / \mathrm{mL}$ & [181] \\
\hline & $\begin{array}{l}\text { Electro-polymerized Poly(neutral } \\
\text { red) film modified with } \mathrm{Fe}_{2} \mathrm{O}_{3} \\
\text { magnetic nanoparticles (MNPs) } \\
\text { embedded with acetylcholinest- } \\
\text { erase (AChE) using glutaraldehyde } \\
\text { (GA) cross-linker }\end{array}$ & Acetylcholine (Ach) & CV and EIS & - & $1.04 \mu \mathrm{M}$ & [182] \\
\hline & $\begin{array}{l}\text { Rare-earth-doped (lanthanide- } \\
\text { doped) upconversion nanoparti- } \\
\text { cles (UCNPs) }\end{array}$ & Dopamine (DA) & Rayleigh light scattering & $0-300 \mu \mathrm{M}$ & $1.62 \mu \mathrm{M}$ & [183] \\
\hline
\end{tabular}

\section{Micro-biosensors to detect urine-based biomarkers}

A group of researchers led by Young have measured urine neural thread protein (UNTP) levels using enzyme-linked sandwich immunosorbent assay (ELISA) method. For this process, they utilized a microtiter plate coated with bispecific receptor antibody having affinity for immunoglobulin G (IgG) and urinary NTP as the measurement platform. With such device, the mean UNTP level was measured to be $26.8 \pm 9.4 \mu \mathrm{g} / \mathrm{mL}$ in samples collected from AD patients, higher than that $(18.1 \pm 6.7 \mu \mathrm{g} / \mathrm{mL})$ in the normal control group [179]. Levy et al. have developed an affinity assay kit using 32-well microtiter plates as enzyme-linked immunosorbent assay for the measurement of neural thread protein (uNTP) using urine samples collected from AD patients. They obtained UNTP levels within a linear range of 10-60 $\mu \mathrm{g} / \mathrm{mL}$ with the help of ELISA technique [180]. $\mathrm{Ku}$ et al. have determined levels of AD7c-NTP in urine samples collected from AD patients using an enzymelinked immunosorbent assay technique for the detection of AD7c-NTP. For this purpose, a microtiter plate was coated with a bispecific receptor antibody having high affinities for rabbit immunoglobulin G (IgG) and AD7c-NTP. Using this kit, the mean AD7c-NTP level in MCI patients was measured to be $32.76 \pm 9 \mu \mathrm{g} / \mathrm{mL}$ [181]. Figure 6 shows a highly sensitive electrochemical biosensor electrode probe fabricated with a potential cycling electro-polymerization of poly(neutral red) (PNR) film modified with $\mathrm{Fe}_{2} \mathrm{O}_{3}$ magnetic nanoparticles immobilized on acetylcholinesterase (AchE) using glutaraldehyde cross-linking. This biosensor device was able to detect acetylcholine (Ach) using CV and EIS techniques with an LOD of $1.04 \mu \mathrm{M}$ [182]. Pulgarin et al. have designed a highly sensitive Rayleigh light scattering sensor for the detection of dopamine (DA) from human urine samples. The sensor device was fabricated using rare-earth-doped (lanthanide-doped) upconversion nanoparticles (UCNPs). The sensor showed a linear range of detection of $0-300 \mu \mathrm{M}$ and an LOD of $1.62 \mu \mathrm{M}$ with a Rayleigh light scattering method [183]. 


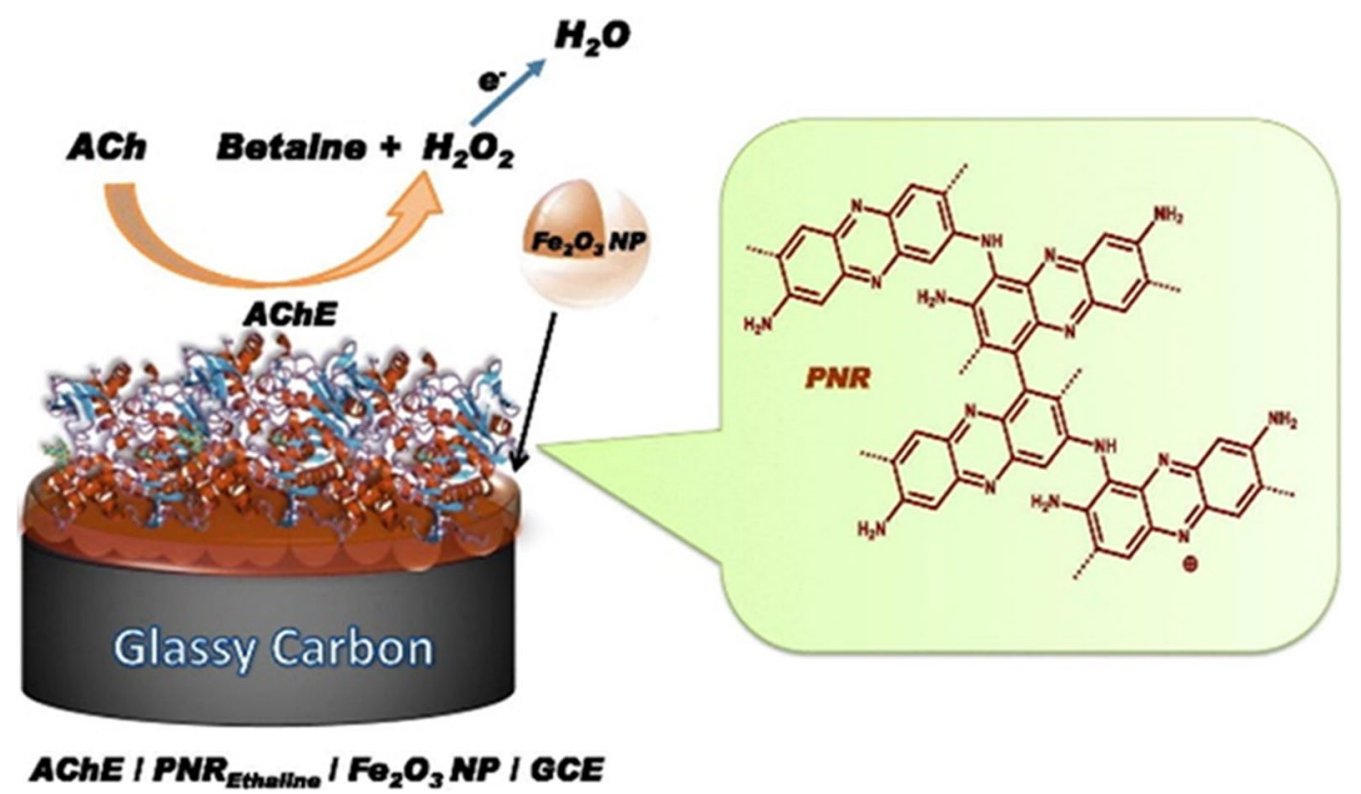

Fig. 6 Iron oxide magnetic nanoparticles on poly(neutral red) film for acetylcholine (Ach) biomarker detection from urine. Reprinted with permission from ref. [182]

\section{Tear-based small biosensors}

Similar to urine, tear is also an important biosample with a non-invasive and easy mode of collection for the detection of AD biomarkers [77]. Tears are clear threelayered bio-fluids that cover the frontal part of the eye ball to keep the eye moist and protect the eye ball from foreign particles. Tears are produced by lacrimal glands of the eyelids via blood plasma filtration. Although tear is an excellent source of various electrolytes, proteins, lipids, nucleotides, and biomolecules, studies on the use of tear-based biosensors for the detection of biomarkers of human diseases are limited [184, 185]. Therefore, there is an unmet need for the design and development of ultrasensitive tear-based biosensors for the monitoring and diagnosis of disease conditions of human body using tear samples [186]. Kenny et al. have used tear samples to detect AD-specific protein along with microRNA-based biomarkers. The protein was detected using a liquid chromatography-mass spectrometry (LC-MS) and microRNA was diagnosed with a genome-wide high-throughput polymerase chain reaction-based platform.

\section{Femto-biosensors to detect tear-based biomarkers}

Until now, there are no documented results in the web library for the detection of AD biomarkers from tearbased samples using femto-level biosensors. Thus, biosensor researchers have plenty of opportunity to focus on the development of highly useful femto-scale biosensors to enhance early diagnosis of $\mathrm{AD}$.

\section{Nano-biosensors to detect tear-based biomarkers}

Some researchers have worked on nano-level detection of AD biomarkers from tear samples. Punj et al. have successfully detected levels of multifunctional chemical messengers known as cytokines with an efficient electrochemical biosensor platform using the amperometric method for measuring chemical conductance as shown in Fig. 7. Immune-analysis of the tear fluids showed a limit of detection of $0.0221 \mathrm{ng} / \mathrm{mL}$ [187].

\section{Micro-biosensors to detect tear-based biomarkers}

Kallo et al. have detected tear-based proteins from tear samples collected from AD patients and healthy controls. They reported an increase in the concentration of tear protein $(8.8 \pm 2.9 \mu \mathrm{g} / \mu \mathrm{L})$ in $\mathrm{AD}$ patients compared to that in normal controls $(4.4 \pm 1.4 \mu \mathrm{g} / \mu \mathrm{L})$. For the measurement of tear proteins, they used the standard method of quantitative proteomics followed by electrophoresis and liquid chromatography-mass spectroscopy/mass spectroscopy (LC-MS/MS) [188].

\section{Sweat-based small biosensors}

Sweat is a body fluid produced by the skin. It is an electrolyte-rich salty solution [189]. Sweat is generally used for electrochemical detection of different metabolites such as uric acid and glucose. It is rarely used for the detection of proteomics because it contains very low concentrations of sweat proteins. This is due to the lower permeability of large protein molecules [190]. 


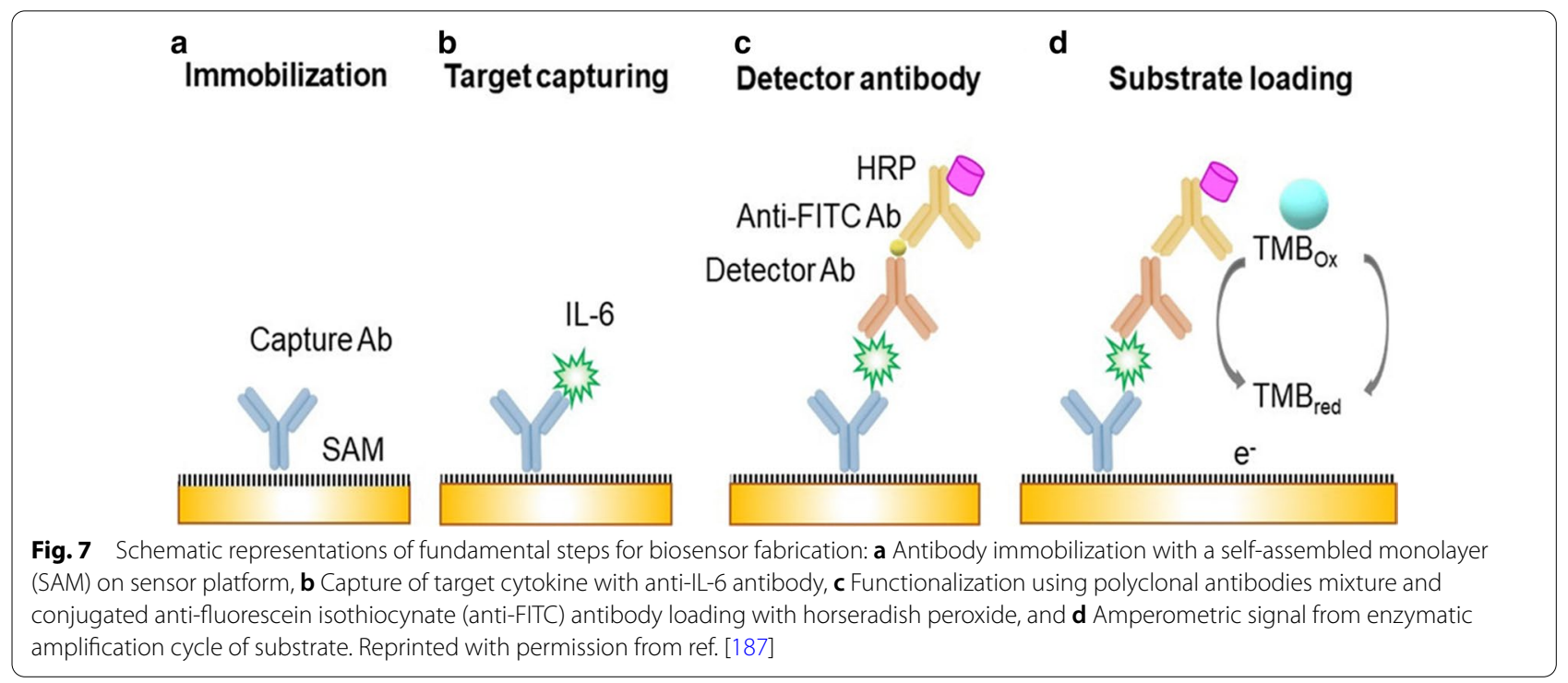

Technological advancement has led to the development of stretchable, biocompatible, and wearable electronic tattoo-like devices for sweat analysis [191].

\section{Femto-biosensors to detect sweat-based biomarkers}

Of all biosamples, sweat is seldom used as a sample for the diagnosis of $\mathrm{AD}$ diseases because it is a very dilute aqueous solution with very low concentrations of proteomics and biomolecules associated with AD. Therefore, a highly sophisticated, advanced, and ultrasensitive femto-level biosensor is required to use sweat for the diagnosis of AD.

\section{Nano-biosensors to detect sweat-based biomarkers}

Until now, there have been few technological advancements showing the applicability of nano-level biosensor for the detection of AD biomarkers from sweat samples. $\mathrm{AD}$ patients are known to have lower concentrations of dopamine (DA) in sweat. Lei et al. have formulated a single-atom doped $\mathrm{MoS}_{2}$ with $\mathrm{Mn}$ for the ultrasensitive detection of DA from an artificial sweat sample, showing a limit of detection of $0.05 \mathrm{nM}$ with the application of cyclic voltammetry and EIS techniques. This may provide a new strategy for pathological diagnosis of $\mathrm{AD}$ with sweat as shown in Fig. 8 [192].

\section{Micro-biosensors to detect sweat-based biomarkers}

Sodium ion present in sweat sample could be used to monitor the health status of AD patients. Elmstahl et al. have estimated that total sodium concentration in sweat samples collected from AD patients using iontophoresis method is $91 \mu \mathrm{m} / \mathrm{mL}$, higher than that in normal controls [193].

\section{Saliva-based small biosensors}

Saliva is the most attractive non-invasive oral matrix could be used as an ideal source of biomarkers for the detection of AD. The use of saliva as a biosample for early detection of $\mathrm{AD}$ has grown with exponential rate in the last decades. The literature shows that it contains majority of proteins found in blood stream and used as an excellent source for the omics profiling process for the qualitative and quantitative characterization of saliva proteins also known as "salvaomics" [194]. There are different techniques like ELISA, qRT-PCR, Luminex assay, antibody conjugated magnetic nanoparticles, mass spectrometry etc. used for the detection of $A \beta$ present in saliva [195]. A $\beta 42$ levels were recorded to almost double in the $\mathrm{AD}$ and $\mathrm{MCI}$ patients compared to normal controls. The value of $\mathrm{A} \beta 42$ when exceeds the level $40 \mathrm{pg} /$ $\mathrm{mL}$ in the salivary secretion than it is regarded to induces the early pathogenic conditions of AD or MIC conditions [196]. Similarly, tau concentration present in salivary is also of little significance, but the higher value of ratio of $\mathrm{p}$-tau/tau is observed in AD and MCI patients [9]. Stem cells present in saliva are aged prematurely and disrupted with the age-factors which could be used for the detection of cell abnormality and correlated for the beta-amyloid plaque formation, a main cause of neurodegenerative disorder appears as AD $[66,197]$. The salivary epithelial cells collected from AD patients demonstrated the alternation of amyloid precursor proteins (APPs) which is supposed to contribute the accumulation of $\beta$-amyloid peptides [198]. Sabbagh et al. used enzyme-linked immunosorbent assay for the quantitative analysis of $A \beta 42$ in saliva sample collected from AD patients and recorded as $51.7 \pm 1.6 \mathrm{pg} / \mathrm{mL}$ which is higher than that of the 

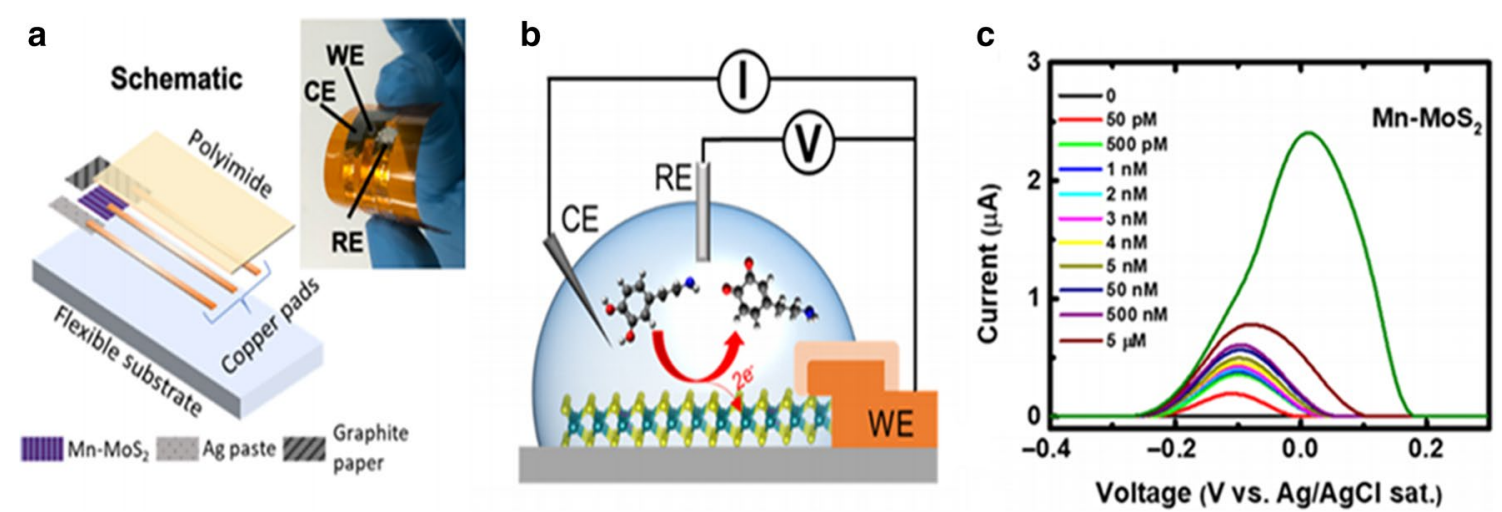

Fig. 8 Fabrication of sweat-based biosensor and its working principle: a An integrated sensor with working (WE), reference (RE), and counter electrode (CE) for DA detection, $\mathbf{b}$ A graphical presentation of testing setup, and (C) DPV graph obtained from the DA sensor. Reprinted with permission from ref. [192]

control group [199]. The conflicting result was reported with saliva as biosamples. Various methods for the analysis of AD biomarkers in saliva-based biosamples still do not show consistent results. The proper quantification and presentation of different biomarkers that are present in very low concentration in saliva must be standardized to eliminate the errors during the accurate identification of saliva-based biomarkers. Therefore, further intensive research and investigation should be conducted for the identifications and validations of protocols with the available diagnostic tools for the early detection and proper management of $\mathrm{AD}$ using saliva as non-invasion biosample.

\section{Future trends in the development of biosensors}

Since there is no therapeutic drug that can stop the progression of $\mathrm{AD}$ or completely recover $\mathrm{AD}$, early diagnosis of $\mathrm{AD}$ is very important. After early diagnosis, symptoms of $\mathrm{AD}$ can be alleviated and the progression of $\mathrm{AD}$ can be slowed through appropriate treatment. Due to this reason, femto-, nano-, and micro-scale biosensing technologies using biosamples are highly promising tools for early diagnosis of onset and progression of AD.

The most significant disadvantage of CSF and bloodbased detection is associated with the invasive method of sample collection. To overcome the current limitation of invasive sampling, the new trend in research is focused on the development of new non-invasive techniques such as an optical-screening or a bio-imaging process for $\mathrm{AD}$ diagnosis. Baksh et al. have used coherent extreme UV (EUV) from an ultrafast laser to create images of samples from mouse hippocampal neurons with the potential for high-resolution element-specific 3D imaging within biological structures. This non-invasive technique has potential applications in AD diagnosis. Kawasaki et al. have also reported a far-infrared (FIR) free-electron laser (FEL) for detecting amyloid protein aggregates in brains of AD patients [200].

Although non-invasive biosamples such as urine, tears, and sweat have been used for the detection of AD biomarkers, low concentrations of AD biomarkers in these samples have limited their use for early detection of AD. For this reason, researchers have made efforts to discover and detect new types of biomarkers from non-invasive body fluids to enhance sensitivities of biosensors. Yan et al. have leveraged a modern technique known as small-input liquid volume extracellular RNA sequencing (SILVER-seq) to generate extracellular RNA (exRNA) profiles of human plasma samples. They discovered that phosphoglycerate dehydrogenase (PHGDH), a unique gene, had consistently higher levels in AD brain transcriptomes and plasma samples from three independent cohorts [201]. Their finding suggests that overproduction of exRNA by PHGDH gene in elderly people could provide an early warning for the development of AD. Similarly, Berdyyeva et al. have discovered a novel AD biomarker for PET imaging tracer ${ }^{\prime}\left({ }^{18} \mathrm{~F}\right) \mathrm{JNJ}-64413739$ in a rat model [202]. It can act as a potential PET tracer of central neuro-inflammation to aid the control and management of $\mathrm{AD}$ before its pathological onset.

Future biosensing techniques for $\mathrm{AD}$ diagnosis can be combined with wearable devices (skin patch, tattoo, masks, contact lenses, wrist watches, and so on) that may also be connected with remote systems for continuous monitoring of patients' health status. Furthermore, when combined with artificial intelligence (AI), the accuracy of AD diagnosis can be further improved. Rapid technological advancement had led to the emergence of digital biomarkers and digital biosensors for early detection and diagnosis of Alzheimer's disease. 
A digital biomarker refers to objective and strategic physiological behavioral data collected and measured through wearable and implantable digital devices [203, 204]. Digital biosensors represent bioanalysis systems logically processed with multiple biochemical signals [205]. The future is facing an inflection point in medical diagnosis of $\mathrm{AD}$ with simultaneous emergence of digital biomarkers and biosensors. Multisignal-based digital biomarkers and biosensors can have a profound impact on early diagnosis of AD.

\section{Conclusions}

We reviewed current development, challenges, and future directions of femto-, nana-, and micro-biosensors using invasive and non-invasive biosamples for early detection of AD. Based on the detection scale from femto to micro levels, analytical performances of small biosensors were summarized depending on specific body fluids (CSF, blood, urine, tear, and sweat) containing AD biomarkers. Also, we summarized detailed sensing techniques to ultrasensitively detect multiple target biomarkers (i.e., $\mathrm{A} \beta$ peptide, tau protein, Ach, etc.) of $\mathrm{AD}$ with regards to detection ranges and limits of detection. We extensively introduced future trends of new noninvasive detection techniques (such as optical screening and bio-imaging process) to hurdle current issue associated with the invasiveness of sample collection (CSF and blood). In addition, discovery of new types of $\mathrm{AD}$ biomarkers from non-invasive body fluids will be challenging for early diagnosis of AD. The future will face an inflection point in early diagnosis of AD with simultaneous emergence of addressable innovative technologies such as new non-invasive detection methods, wearable devices, and new types of ultrasensitive biomarkers, digital biomarkers, and digital biosensors.

\section{Acknowledgements}

The authors acknowledge the Ministry of Science and ICT and also the National Research Foundation of Korea.

\section{Authors' contributions}

HPK wrote and revised the manuscript, JJ and JO conceived the idea, revised and corrected the manuscript, HPK and YJ prepared graphical section. All the authors read and approved the final manuscript.

\section{Funding}

This work was supported by the National Research Foundation of Korea, funded by the Ministry of Science and ICT (Grant Numbers NRF2020R1A4A2002817, 2018R1D1A3B07047434, and 2019R1/1A3A01060695).

\section{Declarations}

\section{Competing interests}

The authors declare that they have no competing interests.

\section{Author details}

${ }^{1}$ Department of Mechanical Design Engineering, College of Engineering, Jeonbuk National University, Jeonju 54896, South Korea. ${ }^{2}$ Department of Nano-bio Mechanical System Engineering, College of Engineering, Jeonbuk National University, Jeonju 54896, South Korea.

Received: 8 January 2021 Accepted: 25 February 2021

Published online: 09 March 2021

References

1. Carlo SF, De Strooper B. Alzheimer's disease mechanisms and emerging roads to novel therapeutics. Annu Rev Neurosci. 2016;39:57-79.

2. Zetterberg $\mathrm{H}$, Bendlin BB. Biomarkers for Alzheimer's disease-preparing for a new era of disease-modifying therapies. Mol Psychiatry. 2020.

3. Zhang Y, Ren B, Zhang D, Liu Y, Zhang M, Zhao C, et al. Design principles and fundamental understanding of biosensors for amyloid- $\beta$ detection. J Mater Chem B. 2020;8(29):6179-96.

4. Khoury R, Ghossoub E. Diagnostic biomarkers of Alzheimer's disease: a state-of-the-art review. Biomarkers Neuropsych. 2019;1:100005.

5. El Kadmiri N, Said N, Slassi I, El Moutawakil B, Nadifi S. Biomarkers for Alzheimer disease: classical and novel candidates' review. Neuroscience. 2018:370:181-90.

6. Kneynsberg A, Combs B, Christensen K, Morfini G, Kanaan NM. Axonal degeneration in tauopathies: disease relevance and underlying mechanisms. Front Neurosci. 2017;11:572.

7. Li LS, Lu YL, Nie J, Xu YY, Zhang W, Yang WJ, et al. Dendrobium nobile lindl alkaloid, a novel autophagy inducer, protects against axonal degeneration induced by $A \beta 25-35$ in hippocampus neurons in vitro. CNS Neurosci Ther. 2017;23(4):329-40.

8. Marquié M, Chong MST, Antón-Fernández A, Verwer EE, SáezCalveras N, Meltzer AC, et al. [F-18]-AV-1451 binding correlates with postmortem neurofibrillary tangle braak staging. Acta Neuropathol. 2017;134(4):619-28.

9. Theofilas P, Ehrenberg AJ, Nguy A, Thackrey JM, Dunlop S, Mejia MB, et al. Probing the correlation of neuronal loss, neurofibrillary tangles, and cell death markers across the Alzheimer's disease braak stages: a quantitative study in humans. Neurobiol Aging. 2018;61:1-12.

10. Blennow K, Hampel H. CSF markers for incipient Alzheimer's disease. Lancet Neurol. 2003;2(10):605-13.

11. Lien TTN, Takamura Y, Tamiya E, Vestergaard MdC. Modified screen printed electrode for development of a highly sensitive label-free impedimetric immunosensor to detect amyloid beta peptides. Anal Chim Acta. 2015;892:69-76.

12. Riedel BC, Thompson PM, Brinton RD. Age. APOE and sex: triad of risk of Alzheimer's disease. J Steroid Biochem Mol Biol. 2016;160:134-47.

13. Lee MC, Yu WC, Shih YH, Chen CY, Guo ZH, Huang SJ, et al. Zinc ion rapidly induces toxic, off-pathway amyloid- $\beta$ oligomers distinct from amyloid- $\beta$ derived diffusible ligands in Alzheimer's disease. Sci Rep. 2018;8(1):1-16.

14. Zhu G, Lee HJ. Electrochemical sandwich-type biosensors for a - 1 antitrypsin with carbon nanotubes and alkaline phosphatase labeled antibody-silver nanoparticles. Biosens Bioelectron. 2017;89:959-63.

15. Bram JMdF, Talib LL, Joaquim HPG, Sarno TA, Gattaz WF, Forlenza OV. Protein levels of ADAM10, BACE1, and PSEN1 in platelets and leukocytes of Alzheimer's disease patients. Eur Arch Psychiatry Clin Neurosci. 2019;269(8):963-72.

16. Sarno TA, Talib LL, Joaquim HPG, Bram JMdF, Gattaz WF, Forlenza OV. Protein expression of BACE1 is downregulated by donepezil in Alzheimer's disease platelets. J Alzheimer's DisJ. 2017;55:1445-51.

17. Zhang Y, Li Y, Wang R, Sha G, Jin H, Ma L. Elevated urinary AD7c-NTP levels in older adults with hypertension and cognitive impairment. J Alzheimer's DisJ. 2020;74:237-44.

18. Cameron JM, Butler HJ, Palmer DS, Baker MJ. Biofluid spectroscopic disease diagnostics: a review on the processes and spectral impact of drying. J Biophotonics. 2018;11(4):e201700299.

19. Broza YY, Zhou X, Yuan M, Qu D, Zheng Y, Vishinkin R, et al. Disease detection with molecular biomarkers: from chemistry of body fluids to nature-inspired chemical sensors. Chem Rev. 2019;119(22):11761-817. 
20. Hampel H, Lista S, Khachaturian ZS. Development of biomarkers to chart all Alzheimer's disease stages: the royal road to cutting the therapeutic Gordian knot. Alzheimers Dement. 2012;8(4):312-36.

21. Sprecher KE, Koscik RL, Carlsson CM, Zetterberg H, Blennow K, Okonkwo OC, et al. Poor sleep is associated with CSF biomarkers of amyloid pathology in cognitively normal adults. Neurology. 2017:89(5):445-53.

22. Remnestål J, Just D, Mitsios N, Fredolini C, Mulder J, Schwenk JM, et al. CSF profiling of the human brain enriched proteome reveals associations of neuromodulin and neurogranin to Alzheimer's disease. Proteomics Clin Appl. 2016;10(12):1242-53.

23. Holth JK, Fritschi SK, Wang C, Pedersen NP, Cirrito JR, Mahan TE, et al. The sleep-wake cycle regulates brain interstitial fluid tau in mice and CSF tau in humans. Science. 2019;363(6429):880-4.

24. García-Ayllón M-S, Lopez-Font I, Boix CP, Fortea J, Sánchez-Valle R, Lleó $A$, et al. C-terminal fragments of the amyloid precursor protein in cerebrospinal fluid as potential biomarkers for Alzheimer disease. Sci Rep. 2017:7(1):1-7.

25. Janelidze S, Mattsson N, Stomrud E, Lindberg O, Palmqvist S, Zetterberg $\mathrm{H}$, et al. CSF biomarkers of neuroinflammation and cerebrovascular dysfunction in early Alzheimer disease. Neurology. 2018;91(9):e867-e77.

26. Zetterberg H. Cerebrospinal fluid biomarkers for Alzheimer's disease: current limitations and recent developments. Curr Opin Psychiatry. 2015;28(5):402-9.

27. Duits FH, Martinez-Lage P, Paquet C, Engelborghs S, Lleó A, Hausner L, et al. Performance and complications of lumbar puncture in memory clinics: results of the multicenter lumbar puncture feasibility study. Alzheimers Dement. 2016;12(2):154-63.

28. Hansson O, Lehmann S, Otto M, Zetterberg H, Lewczuk P. Advantages and disadvantages of the use of the CSF amyloid $\beta$ (A $\beta$ ) $42 / 40$ ratio in the diagnosis of Alzheimer's disease. Alzheimer's Res Ther. 2019;11(1):34

29. Lau H-C, Lee I-K, Ko P-W, Lee H-W, Huh J-S, Cho W-J, et al. Non-invasive screening for Alzheimer's disease by sensing salivary sugar using drosophila cells expressing gustatory receptor (Gr5a) immobilized on an extended gate ion-sensitive field-effect transistor (EG-ISFET) biosensor. PLoS One. 2015;10(2):e0117810.

30. Hartmann S, Ledur Kist TB. A review of biomarkers of Alzheimer's disease in noninvasive samples. Biomark Med. 2018;12(6):677-90.

31. Gisslén M, Price RW, Andreasson U, Norgren N, Nilsson S, Hagberg L, et al. Plasma concentration of the neurofilament light protein (NFL) is a biomarker of CNS injury in HIV infection: a cross-sectional study. EBioMedicine. 2016;3:135-40.

32. Shui B, Tao D, Florea A, Cheng J, Zhao Q, Gu Y, et al. Biosensors for Alzheimer's disease biomarker detection: a review. Biochimie. 2018;147:13-24

33. Azimzadeh M, Nasirizadeh $N$, Rahaie M, Naderi-Manesh $\mathrm{H}$. Early detection of Alzheimer's disease using a biosensor based on electrochemically-reduced graphene oxide and gold nanowires for the quantification of serum microRNA-137. RSC Adv. 2017;7(88):55709-19.

34. Brazaca LC, Sampaio I, Zucolotto V, Janegitz BC. Applications of biosensors in Alzheimer's disease diagnosis. Talanta. 2020;210:120644.

35. Kiddle SJ, Voyle N, Dobson RJB. A blood test for Alzheimer's disease: progress, challenges, and recommendations. J Alzheimers Dis. 2018;64(s1):289-S97.

36. Sjögren $M$, Vanderstichele $H$, Ågren $H$, Zachrisson O, Edsbagge M, Wikkelsø $C$, et al. Tau and $A \beta 42$ in cerebrospinal fluid from healthy adults 21-93 years of age: establishment of reference values. Clin Chem. 2001;47(10):1776-81.

37. Hampel H, O'Bryant SE, Molinuevo JL, Zetterberg H, Masters CL, Lista S, et al. Blood-based biomarkers for Alzheimer disease: mapping the road to the clinic. Nat Rev Neurol. 2018;14(11):639-52.

38. Zetterberg H, Wilson D, Andreasson U, Minthon L, Blennow K, Randall $J$, et al. Plasma tau levels in Alzheimer's disease. Alzheimer's Res Ther. 2013;5(2):9.

39. Kiani ME. Systems and methods for calibrating minimally invasive and non-invasive physiological sensor devices. Google Patents; 2015.

40. Ortiz-Quintero B. Cell-free microRNAs in blood and other body fluids, as cancer biomarkers. Cell Prolif. 2016;49(3):281-303.
41. Lee SH, Kim I, Chung BC. Increased urinary level of oxidized nucleosides in patients with mild-to-moderate Alzheimer's disease. Clin Biochem. 2007:40(13-14):936-8.

42. Oğuzhan Z, Alpaslan K, Ufuk E, Mehmet S, Levent I, Dogan Y. Urinary 8-Hydroxy-2'-deoxyguanosine level and plasma paraoxonase 1 activity with Alzheimer's disease. Clin Chem Lab Med. 2012;50(3):529-34.

43. Tsai P, Evans J, Green K, Sullivan R, Schaumberg D, Richards S, et al. Proteomic analysis of human meibomian gland secretions. Br J Ophthalmol. 2006;90(3):372-7.

44. Boehm D, Keller K, Pieter J, Boehm N, Wolters D, Siggelkow W, et al. Comparison of tear protein levels in breast cancer patients and healthy controls using a De Novo proteomic approach. Oncol Rep. 2012;28(2):429-38.

45. Craig-Schapiro R, Fagan AM, Holtzman DM. Biomarkers of Alzheimer's disease. Neurobiol Dis. 2009;35(2):128-40.

46. De Souza GA, De Godoy LM, Mann M. Identification of 491 proteins in the tear fluid proteome reveals a large number of proteases and protease inhibitors. Genome Biol. 2006;7(8):R72.

47. Fisher CK, Smith AM, Walsh JR. Machine learning for comprehensive forecasting of Alzheimer's disease progression. Sci Rep. 2019;9(1):13622.

48. Collins FS, Varmus H. A new initiative on precision medicine. N Engl J Med. 2015;372(9):793-5.

49. Chen L-C, Wang E, Tai C-S, Chiu Y-C, Li C-W, Lin Y-R, et al. Improving the reproducibility, accuracy, and stability of an electrochemical biosensor platform for point-of-care use. Biosens Bioelectron. 2020;155:112111.

50. Yi X, Feng C, Hu S, Li H, Wang J. Surface plasmon resonance biosensors for simultaneous monitoring of amyloid-beta oligomers and fibrils and screening of select modulators. Analyst. 2016;141(1):331-6.

51. Andreasen N, Hesse C, Davidsson P, Minthon L, Wallin A, Winblad B, et al. Cerebrospinal fluid $\beta$-Amyloid (1-42) in Alzheimer disease: differences between early-and late-onset Alzheimer disease and stability during the course of disease. AMA Arch Neurol. 1999;56(6):673-80.

52. Vanmechelen $E$, Vanderstichele $H$, Davidsson $P$, Van Kerschaver E, Van Der Perre B, Sjögren M, et al. Quantification of tau phosphorylated at threonine 181 in human cerebrospinal fluid: a sandwich ELISA with a synthetic phosphopeptide for standardization. Neurosci Lett. 2000;285(1):49-52.

53. Malima A, Siavoshi S, Musacchio T, Upponi J, Yilmaz C, Somu S, et al. Highly sensitive microscale in vivo sensor enabled by electrophoretic assembly of nanoparticles for multiple biomarker detection. Lab Chip. 2012;12(22):4748-54.

54. Lv S, Zhang K, Zhu L, Tang D. ZIF-8-assisted NaYF4: Yb, Tm@ ZnO converter with exonuclease III-powered DNA walker for near-infrared light responsive biosensor. Anal Chem. 2019;92(1):1470-6.

55. Andreasson $\mathrm{U}$, Blennow $\mathrm{K}$, Zetterberg $\mathrm{H}$. Update on ultrasensitive technologies to facilitate research on blood biomarkers for central nervous system disorders. Alzheimer's Dementia: Diagnosis Assessment Disease Monitoring. 2016;3:98-102.

56. Tzen K-Y, Yang S-Y, Chen T-F, Cheng T-W, Horng H-E, Wen H-P, et al. Plasma $A \beta$ but not tau is related to brain PiB retention in early Alzheimer's disease. ACS Chem Neurosci. 2014;5(9):830-6.

57. Hall RJ, Watne LO, Cunningham E, Zetterberg H, Shenkin SD, Wyller TB, et al. CSF biomarkers in delirium: a systematic review. Int J Geriatr Psychiatry. 2018;33(11):1479-500.

58. Mobed A, Hasanzadeh M. Biosensing: the best alternative for conventional methods in detection of Alzheimer's disease biomarkers. Int J Biol Macromol. 2020;161:59-71.

59. Ameri M, Shabaninejad Z, Movahedpour A, Sahebkar A, Mohammadi $S$, Hosseindoost $S$, et al. Biosensors for detection of tau protein as an Alzheimer's disease marker. Int J Biol Macromol. 2020;162:1100-8.

60. Ettcheto M, Busquets O, Espinosa-Jiménez T, Verdaguer E, Auladell C, Camins A. A chronological review of potential disease-modifying therapeutic strategies for Alzheimer's disease. Curr Pharm Des. 2020;26(12):1286-99.

61. Simonsen AH, Herukka S-K, Andreasen N, Baldeiras I, Bjerke M, Blennow $\mathrm{K}$, et al. Recommendations for CSF AD biomarkers in the diagnostic evaluation of dementia. Alzheimers Dement. 2017;13(3):274-84.

62. Schindler SE, Gray JD, Gordon BA, Xiong C, Batrla-Utermann R, Quan M, et al. Cerebrospinal fluid biomarkers measured by elecsys assays compared to amyloid imaging. Alzheimers Dement. 2018;14(11):1460-9. 
63. Bittner T, Zetterberg H, Teunissen CE, Ostlund RE, Militello M, Andreasson $U$, et al. Technical performance of a novel, fully automated electrochemiluminescence immunoassay for the quantitation of $\beta$-amyloid (1-42) in human cerebrospinal fluid. Alzheimers Dement. 2016;12(5):517-26.

64. Montagne A, Barnes SR, Sweeney MD, Halliday MR, Sagare AP, Zhao Z, et al. Blood-brain barrier breakdown in the aging human hippocampus. Neuron. 2015;85(2):296-302.

65. Bjerke M, Engelborghs S. Cerebrospinal fluid biomarkers for early and differential Alzheimer's disease diagnosis. J Alzheimer's DisJ. 2018;62(3):1199-209.

66. Carneiro P, Morais S, do Carmo Pereira M. Biosensors on the road to early diagnostic and surveillance of Alzheimer's disease. Talanta. 2020;211:120700.

67. Park D, Kim JH, Kim HJ, Lee D, Lee DS, Yoon DS, et al. Multiplexed femtomolar detection of Alzheimer's disease biomarkers in biofluids using a reduced graphene oxide field-effect transistor. Biosens Bioelectron. 2020;167:112505.

68. Bohnstedt KC, Karlberg B, Wahlund L-O, Jönhagen ME, Basun H, Schmidt $\mathrm{S}$. Determination of isoprostanes in urine samples from Alzheimer patients using porous graphitic carbon liquid chromatography-tandem mass spectrometry. J Chromatogr B. 2003;796(1):11-9.

69. Praticò D, Clark CM, Liun F, Lee VY-M, Trojanowski JQ. Increase of brain oxidative stress in mild cognitive impairment: a possible predictor of Alzheimer disease. AMA Arch Neurol. 2002;59(6):972-6.

70. García-Blanco A, Peña-Bautista C, Oger C, Vigor C, Galano J-M, Durand $\mathrm{T}$, et al. Reliable determination of new lipid peroxidation compounds as potential early Alzheimer disease biomarkers. Talanta. 2018;184:193-201.

71. Dunstan R, Sparkes D, Macdonald M, De Jonge XJ, Dascombe B, Gottfries J, et al. Diverse characteristics of the urinary excretion of amino acids in humans and the use of amino acid supplementation to reduce fatigue and sub-health in adults. J Nutr. 2017;16(1):19.

72. Gackowski D, Rozalski R, Siomek A, Dziaman T, Nicpon K, Klimarczyk $\mathrm{M}$, et al. Oxidative stress and oxidative DNA damage is characteristic for mixed Alzheimer disease/vascular Dementia. J Neurol Sci. 2008;266(1-2):57-62.

73. Koronyo-Hamaoui M, Koronyo Y, Ljubimov AV, Miller CA, Ko MK, Black $\mathrm{KL}$, et al. Identification of amyloid plaques in retinas from Alzheimer's patients and noninvasive in vivo optical imaging of retinal plaques in a mouse model. Neurolmage. 2011;54:204-S17.

74. Fullard RJ, Snyder C. Protein levels in nonstimulated and stimulated tears of normal human subjects. Investig Ophthalmol Vis Sci. 1990;31(6):1119-26.

75. Csősz É, Boross P, Csutak A, Berta A, Tóth F, Póliska S, et al. Quantitative analysis of proteins in the tear fluid of patients with diabetic retinopathy. J Proteomics. 2012;75(7):2196-204

76. Zhou L, Beuerman RW, Chan CM, Zhao SZ, Li XR, Yang H, et al. Identification of tear fluid biomarkers in dry eye syndrome using iTRAQ quantitative proteomics. J Proteome Res. 2009;8(11):4889-905.

77. Zhou L, Zhao SZ, Koh SK, Chen L, Vaz C, Tanavde V, et al. In-depth analysis of the human tear proteome. J Proteom. 2012;75(13):3877-85.

78. Baker LB, Wolfe AS. Physiological mechanisms determining eccrine sweat composition. Eur J Appl Physiol. 2020;120(9):719-52.

79. Heikenfeld J. Non-invasive analyte access and sensing through eccrine sweat: challenges and outlook circa 2016. Electroanalysis. 2016;28(6):1242-9.

80. Mugo SM, Dhanjai, Alberkant J. A biomimetric lactate imprinted smart polymers as capacitive sweat sensors. EEE Sens J. 2020;20(11):5741-9.

81. Gao W, Brooks GA, Klonoff DC. Wearable physiological systems and technologies for metabolic monitoring. J Appl Physiol. 2017;124(3):548-56.

82. Heikenfeld J, Jajack A, Rogers J, Gutruf P, Tian L, Pan T, et al. Wearable sensors: modalities, challenges, and prospects. Lab Chip. 2018;18(2):217-48.

83. Baker LB. Physiology of sweat gland function: the roles of sweating and sweat composition in human health. Temperature. 2019;6(3):211-59.

84. Csősz É, Emri G, Kalló G, Tsaprailis G, Tőzsér J. Highly abundant defense proteins in human sweat as revealed by targeted proteomics and label-free quantification mass spectrometry. J Eur Acad Dermatol. 2015;29(10):2024-31 .
85. Hauke A, Simmers P, Ojha YR, Cameron BD, Ballweg R, Zhang T, et al. Complete validation of a continuous and blood-correlated sweat biosensing device with integrated sweat stimulation. Lab Chip. 2018;18(24):3750-9.

86. Rapado-González Ó, Martínez-Reglero C, Salgado-Barreira Á, Takkouche B, López-López R, Suárez-Cunqueiro MM, et al. Salivary biomarkers for cancer diagnosis: a meta-analysis. Ann Med. 2020;52(3-4):131-44.

87. Sarkar A, Kuehl MN, Alman AC, Burkhardt BR. Linking the oral microbiome and salivary cytokine abundance to circadian oscillations. Sci Rep. 2021;11(1):2658.

88. Tvarijonaviciute A, Zamora C, Ceron JJ, Bravo-Cantero AF, Pardo-Marin L, Valverde S, et al. Salivary biomarkers in Alzheimer's disease. Clin Oral Investig. 2020;24(10):3437-44.

89. Kodintsev AN, Kovtun OP, Volkova LI. Saliva Biomarkers in Diagnostics of Early Stages of Alzheimer's Disease. Neurochem J. 2020;14(4):429-38.

90. Farah R, Haraty H, Salame Z, Fares Y, Ojcius DM, Said Sadier N. Salivary biomarkers for the diagnosis and monitoring of neurological diseases. Biomed J. 2018:41(2):63-87.

91. Mohamed WA, Salama RM, Schaalan MF. A pilot study on the effect of lactoferrin on Alzheimer's disease pathological sequelae: Impact of the p-Akt/PTEN pathway. Biomed. 2019;111:714-23.

92. González-Sánchez M, Bartolome F, Antequera D, Puertas-Martín V, González P, Gómez-Grande A, et al. Decreased salivary lactoferrin levels are specific to Alzheimer's disease. EBioMedicine. 2020;57:102834.

93. Liang D, Lu H. Salivary biological biomarkers for Alzheimer's disease. Arch Oral Biol. 2019;105:5-12.

94. Lee JC, Kim SJ, Hong S, Kim Y. Diagnosis of Alzheimer's disease utilizing amyloid and tau as fluid biomarkers. Exp Mol Med. 2019;51(5):1-10.

95. Passali GC, Politi L, Crisanti A, Loglisci M, Anzivino R, Passali D. Tau protein detection in anosmic Alzheimer's disease patient's nasal secretions. Chemosens Percept. 2015;8(4):201-6.

96. Yahiaoui-Doktor M, LuckT, Riedel-Heller SG, Loeffler M, Wirkner K, Engel C. Olfactory function is associated with cognitive performance: results from the population-based LIFE-Adult-Study. Alzheimer's Res Ther. 2019;11(1):43.

97. Espíndola SL, Damianich A, Alvarez RJ, Sartor M, Belforte JE, Ferrario JE, et al. Modulation of tau isoforms imbalance precludes tau pathology and cognitive decline in a mouse model of tauopathy. Cell Rep. 2018;23(3):709-15.

98. Adams SJ, DeTure MA, McBride M, Dickson DW, Petrucelli L. Three repeat isoforms of tau inhibit assembly of four repeat tau filaments. PLoS One. 2010;5(5):e10810.

99. Guo T, Noble W, Hanger DP. Roles of tau protein in health and disease. Acta Neuropathol. 2017;133(5):665-704.

100. Castellani RJ, Perry G. Tau biology, tauopathy, traumatic brain injury, and diagnostic challenges. J Alzheimer's DisJ. 2019;67(2):447-67.

101. Wu L, Wang Z, Ladd S, Dougharty DT, Madhavan SS, Marcus M, et al. Human tau isoform aggregation and selective detection of misfolded tau from post-mortem Alzheimer's disease brains. bioRxiv. 2020:1-31.

102. Pradeepkiran JA, Reddy AP, Reddy PH. Pharmacophore-based models for therapeutic drugs against phosphorylated tau in Alzheimer's disease. Drug Discov Today. 2019;24(2):616-23.

103. Chung DC, Carlomagno Y, Cook CN, Jansen West K, Daughrity L, Lewis Tuffin $L$, et al. Tau exhibits unique seeding properties in globular glial tauopathy. Acta Neuropathol Commun. 2019;7(1):1-12.

104. Götz J, Eckert A, Matamales M, Ittner LM, Liu X. Modes of A $\beta$ toxicity in Alzheimer's disease. Cell Mol Life Sci. 2011;68(20):3359-75.

105. Mairet-Coello G, Courchet J, Pieraut S, Courchet V, Maximov A, Polleux F. The CAMKK2-AMPK kinase pathway mediates the synaptotoxic effects of $A \beta$ oligomers through tau phosphorylation. Neuron. 2013;78(1):94-108.

106. Younan ND, Chen K-F, Rose R-S, Crowther DC, Viles JH. Prion protein stabilizes amyloid- $\beta$ ( $A \beta$ ) oligomers and enhances $A \beta$ neurotoxicity in a Drosophila model of Alzheimer's disease. Biol Chem. 2018;293(34):13090-9.

107. Forloni G, Balducci C. Alzheimer's disease, oligomers, and inflammation. J Alzheimer's DisJ. 2018;62(3):1261-76.

108. Sengupta U, Nilson AN, Kayed R. The role of amyloid- $\beta$ oligomers in toxicity, propagation, and immunotherapy. EBioMedicine. 2016;6:42-9.

109. Selkoe DJ, Hardy J. The amyloid hypothesis of Alzheimer's disease at 25 years. EMBO Mol Med. 2016;8(6):595-608. 
110. Lashley T, Schott JM, Weston P, Murray CE, Wellington $H$, Keshavan $A$, et al. Molecular biomarkers of Alzheimer's disease: progress and prospects. Dis Models Mech. 2018;11(5):1-9.

111. Quevenco FC, van Bergen JM, Treyer V, Studer ST, Kagerer SM, Meyer R, et al. Functional brain network connectivity patterns associated with normal cognition at old-age, local $\beta$-amyloid, tau, and APOE4. Front Aging Neurosci. 2020:12:1-11.

112. Nazem A, Mansoori GA. Nanotechnology for Alzheimer's disease detection and treatment. Insciences J. 2011:1(4):169-93.

113. Hardy J, Selkoe DJ. The amyloid hypothesis of Alzheimer's disease: progress and problems on the road to therapeutics. Science. 2002;297(5580):353-6.

114. Hampel H, Vassar R, De Strooper B, Hardy J, Willem M, Singh N, et al. The $\beta$-secretase BACE1 in Alzheimer's disease. Biol Psychiatry. 2020.

115. Maes OC, Kravitz S, Mawal Y, Su H, Liberman A, Mehindate K, et al. Characterization of a 1 -antitrypsin as a heme oxygenase-1 suppressor in Alzheimer plasma. Neurobiol Dis. 2006;24(1):89-100.

116. Ma L, Wang R, Han Y, Sheng S, Zhu J, Ji Z, et al. Development of a novel urine Alzheimer-associated neuronal thread protein ELISA kit and its potential use in the diagnosis of Alzheimer's disease. J Clin Lab Anal. 2016;30(4):308-14.

117. Disanto G, Barro C, Benkert P, Naegelin Y, Schädelin S, Giardiello A, et al, Serum neurofilament light: a biomarker of neuronal damage in multiple sclerosis. Ann Neurol. 2017;81(6):857-70.

118. Tien YT, Lee WJ, Liao YC, Wang WF, Jhang KM, Wang SJ, et al. Plasma transthyretin as a predictor of amnestic mild cognitive impairment conversion to Dementia. Sci Rep. 2019:9(1):1-7.

119. O'Bryant SE, Lista S, Rissman RA, Edwards M, Zhang F, Hall J, et al. Comparing biological markers of Alzheimer's disease across blood fraction and platforms: comparing apples to oranges. Alzheimer's Dementia: Diagnosis Assessment Disease Monitoring. 2016;3(1):27-34.

120. Huynh RA, Mohan C. Alzheimer's disease: biomarkers in the genome, blood, and cerebrospinal fluid. Front Neurol. 2017:8:1-15.

121. Tropea TF, Xie SX, Rick J, Chahine LM, Dahodwala N, Doshi J, et al. APOE, thought disorder, and SPARE-AD predict cognitive decline in established Parkinson's disease. Mov Disord. 2018;33(2):289-97.

122. Rostgaard N, Waldemar G, Nielsen JE, Simonsen AH. Cerebrospinal fluid biomarkers in familial forms of Alzheimer's disease and frontotemporal Dementia. Dement Geriatr Cogn Disord. 2015;40(1-2):54-62.

123. Yoshida T, Akiba J, Matsui T, Nakamura K, Hisamoto T, Abe M, et al. Pigment epithelium-derived factor (PEDF) prevents hepatic fat storage, inflammation, and fibrosis in dietary steatohepatitis of mice. Dig Dis Sci. 2017;62(6):1527-36.

124. Kallianpur AR, Gittleman $H$, Letendre S, Ellis R, Barnholtz-Sloan JS, Bush WS, et al. Cerebrospinal fluid ceruloplasmin, haptoglobin, and vascular endothelial growth factor are associated with neurocognitive impairment in adults with HIV infection. Mol Neurobiol. 2019:56(5):3808-18.

125. Tumani H, Teunissen C, Süssmuth S, Otto M, Ludolph AC, Brettschneider J. Cerebrospinal fluid biomarkers of neurodegeneration in chronic neurological diseases. Expert Rev Mol Diagn. 2008;8(4):479-94.

126. Davidsson P, Sjögren M, Andreasen N, Lindbjer M, Nilsson CL, WestmanBrinkmalm A, et al. Studies of the pathophysiological mechanisms in frontotemporal Dementia by proteome analysis of CSF proteins. Brain Res Mol Brain Res. 2002;109(1-2):128-33.

127. Tamaoka A, Sekijima Y, Matsuno S, Tokuda T, Shoji SI, Ikeda SI. Amyloid $\beta$ protein species in cerebrospinal fluid and in brain from patients with Down's syndrome. Ann Neurol. 1999;46(6):933-.

128. Tapiola T, Soininen H, Pirttilä T. CSF tau and A 442 levels in patients with Down's syndrome. Neurology. 2001;56(7):979

129. Blennow K, Dubois B, Fagan AM, Lewczuk P, de Leon MJ, Hampel H. Clinical utility of cerebrospinal fluid biomarkers in the diagnosis of early Alzheimer's disease. Alzheimers Dement. 2015;11(1):58-69.

130. Bacioglu M, Maia Luis F, Preische O, Schelle J, Apel A, Kaeser Stephan A, et al. Neurofilament light chain in blood and CSF as marker of disease progression in mouse models and in neurodegenerative diseases. Neuron. 2016:91(1):56-66.

131. Kang MK, Lee J, Nguyen AH, Sim SJ. Label-free detection of ApoE4mediated $\beta$-amyloid aggregation on single nanoparticle uncovering Alzheimer's disease. Biosens Bioelectron. 2015;72:197-204.
132. Li S-S, Lin C-W, Wei K-C, Huang C-Y, Hsu P-H, Liu H-L, et al. Non-invasive screening for early alzheimer's disease diagnosis by a sensitively immunomagnetic biosensor. Sci Rep. 2016;6(1):25155.

133. Zhao G, Wang Y, Li X, Yue Q, Dong X, Du B, et al. Dual-quenching electrochemiluminescence strategy based on three-dimensional metal-organic frameworks for ultrasensitive detection of amyloid- $\beta$. Anal Chem. 2019:91(3):1989-96.

134. Qin J, Cho M, Lee Y. Ultrasensitive detection of amyloid- $\beta$ using cellular prion protein on the highly conductive Au nanoparticles-poly(3,4ethylene dioxythiophene)-poly(thiophene-3-acetic acid) composite electrode. Anal Chem. 2019;91(17):11259-65.

135. Zhang X, Liu S, Song X, Wang H, Wang J, Wang Y, et al. Robust and universal SERS sensing platform for multiplexed detection of Alzheimer's disease core biomarkers using PAapt-AuNPs conjugates. ACS Sens. 2019;4(8):2140-9.

136. Derkus B, Acar Bozkurt P, Tulu M, Emregul KC, Yucesan C, Emregul E. Simultaneous quantification of myelin basic protein and tau proteins in cerebrospinal fluid and serum of multiple sclerosis patients using nanoimmunosensor. Biosens Bioelectron. 2017:89:781-8.

137. Yu Y, Wang P, Zhu X, Peng Q, Zhou Y, Yin T, et al. Combined determination of copper ions and $\beta$-amyloid peptide by a single ratiometric electrochemical biosensor. Analyst. 2018;143(1):323-31.

138. Ly TN, Park S. High performance detection of Alzheimer's disease biomarkers based on localized surface plasmon resonance. J Ind Eng Chem. 2020;91:182-90.

139. Qin J, Jo DG, Cho M, Lee Y. Monitoring of early diagnosis of Alzheimer's disease using the cellular prion protein and poly(Pyrrole-2-carboxylic acid) modified electrode. Biosens Bioelectron. 2018;113:82-7.

140. Liu L, Xia N, Zhang J, Mao W, Wu Y, Ge X. A graphene oxide-based fluorescent platform for selective detection of amyloid- $\beta$ ligomers. Anal Methods. 2015:7(20):8727-32.

141. Esteves-Villanueva JO, Trzeciakiewicz H, Martic S. A protein-based electrochemical biosensor for detection of tau protein, a neurodegenerative disease biomarker. Analyst. 2014;139(11):2823-31.

142. Monte SM, Ghanbari K, Frey WH, Beheshti I, Averback P, Hauser SL, et al. Characterization of the AD7C-NTP cDNA expression in Alzheimer's disease and measurement of a $41-\mathrm{kD}$ protein in cerebrospinal fluid. J Clin Inv. 1997;100(12):3093-104.

143. Ghanbari K, Ghanbari HA. A sandwich enzyme immunoassay for measuring AD7C-NTP as an Alzheimer's disease marker: AD7C test. J Clin Lab Anal. 1998;12(4):223-6.

144. Chae MS, Yoo YK, Kim J, Kim TG, Hwang KS. Graphene-based enzymemodified field-effect transistor biosensor for monitoring drug effects in Alzheimer's disease treatment. Sens Actuators B Chem. 2018;272:448-58

145. Ransohoff RM, Kivisäkk P, Kidd G. Three or more routes for leukocyte migration into the central nervous system. Nat Rev Immunol. 2003;3(7):569-81.

146. Kim K, Kim MJ, Kim DW, Kim SY, Park S, Park CB. Clinically accurate diagnosis of Alzheimer's disease via multiplexed sensing of core biomarkers in human plasma. Nat Commun. 2020;11(1):119.

147. Diba FS, Kim S, Lee HJ. Electrochemical immunoassay for amyloid-beta 1-42 peptide in biological fluids interfacing with a gold nanoparticle modified carbon surface. Catal Today. 2017;295:41-7.

148. Demeritte T, Viraka Nellore BP, Kanchanapally R, Sinha SS, Pramanik A, Chavva SR, et al. Hybrid graphene oxide based plasmonic-magnetic multifunctional nanoplatform for selective separation and label-free identification of Alzheimer's disease biomarkers. ACS Appl Mater Interfaces. 2015;7(24):13693-700.

149. Yoo YK, Kim J, Kim G, Kim YS, Kim HY, Lee S, et al. A highly sensitive plasma-based amyloid- $\beta$ detection system through medium-changing and noise cancellation system for early diagnosis of the Alzheimer's disease. Sci Rep. 2017;7(1):8882.

150. Li X, Jiang M, Cheng J, Ye M, Zhang W, Jaffrezic-Renault N, et al. Signal multi-amplified electrochemical biosensor for voltammetric determination of tau-441 protein in biological samples using carbon nanomaterials and gold nanoparticles to hint dementia. Microchim Acta. 2020;187(5):302.

151. Kim K, Park CB. Femtomolar sensing of Alzheimer's tau proteins by water oxidation-coupled photoelectrochemical platform. Biosens Bioelectron. 2020:154:112075. 
152. De Oliveira TR, Erbereli CR, Manzine PR, Magalhães TNC, Balthazar MLF, Cominetti MR, et al. Early diagnosis of Alzheimer's disease in blood using a disposable electrochemical microfluidic platform. ACS Sens. 2020;5(4):1010-9.

153. Kim S, Wark AW, Lee HJ. Femtomolar detection of tau proteins in undiluted plasma using surface plasmon resonance. Anal Chem. 2016;88(15):7793-9.

154. Kim S, Park JW, Wark AW, Jhung SH, Lee HJ. Tandem femto- and nanomolar analysis of two protein biomarkers in plasma on a single mixed antibody monolayer surface using surface plasmon resonance. Anal Chem. 2017;89(22):12562-8.

155. Wang J-X, Zhuo Y, Zhou Y, Wang H-J, Yuan R, Chai Y-Q. Ceria doped zinc oxide nanoflowers enhanced luminol-based electrochemiluminescence immunosensor for amyloid- $\beta$ detection. ACS Appl Mater Interfaces. 2016;8(20):12968-75.

156. Shui B, Tao D, Cheng J, Mei Y, Jaffrezic-Renault N, Guo Z. A novel electrochemical aptamer-antibody sandwich assay for the detection of tau-381 in human serum. Analyst. 2018;143(15):3549-54.

157. Zengin A, Tamer U, Caykara T. A SERS-based sandwich assay for ultrasensitive and selective detection of Alzheimer's tau protein. Biomacromol. 2013;14(9):3001-9.

158. Kim H, Lee JU, Song S, Kim S, Sim SJ. A shape-code nanoplasmonic biosensor for multiplex detection of Alzheimer's disease biomarkers. Biosens Bioelectron. 2018;101:96-102.

159. Kang D-Y, Lee J-H, Oh B-K, Choi J-W. Ultra-sensitive immunosensor for $\beta$-Amyloid (1-42) using scanning tunneling microscopy-based electrical detection. Biosens Bioelectron. 2009;24(5):1431-6.

160. Wang SX, Acha D, Shah AJ, Hills F, Roitt I, Demosthenous A, et al. Detection of the tau protein in human serum by a sensitive four-electrode electrochemical biosensor. Biosens Bioelectron. 2017;92:482-8.

161. Ren X, Yan J, Wu D, Wei Q, Wan Y. Nanobody-based apolipoprotein E immunosensor for point-of-care testing. ACS Sens. 2017;2(9):1267-71.

162. Yoo YK, Yoon DS, Kim G, Kim J, Han SI, Lee J, et al. An enhanced platform to analyse low-affinity amyloid $\beta$ protein by integration of electrical detection and preconcentrator. Sci Rep. 2017:7(1):14303.

163. Kim H, Lee JU, Kim S, Song S, Sim SJ. A nanoplasmonic biosensor for ultrasensitive detection of Alzheimer's disease biomarker using a chaotropic agent. ACS Sens. 2019:4(3):595-602.

164. Kurkina T, Sundaram S, Sundaram RS, Re F, Masserini M, Kern K, et al. Self-assembled electrical biodetector based on reduced graphene oxide. ACS Nano. 2012;6(6):5514-20.

165. Medina-Sánchez M, Miserere S, Morales-Narváez E, Merkoçi A. On-chip magneto-immunoassay for Alzheimer's biomarker electrochemical detection by using quantum dots as labels. Biosens Bioelectron. 2014;54:279-84.

166. Qu F, Yang M, Rasooly A. Dual signal amplification electrochemical biosensor for monitoring the activity and inhibition of the Alzheimer's related protease $\beta$-secretase. Anal Chem. 2016;88(21):10559-65.

167. Ziu I, Laryea ET, Alashkar F, Wu CG, Martic S. A dip-and-read optical optasensor for detection of tau protein. Anal Bioanal Chem. 2020;412(5):1193-201.

168. Negahdary M, Heli H. An ultrasensitive electrochemical aptasensor for early diagnosis of Alzheimer's disease, using a fern leaves-like gold nanostructure. Talanta. 2019;198:510-7.

169. Hu T, Lu S, Chen C, Sun J, Yang X. Colorimetric sandwich immunosensor for $A \beta(1-42)$ based on dual antibody-modified gold nanoparticles. Sens Actuators B Chem. 2017;243:792-9.

170. Dai Y, Molazemhosseini A, Liu CC. In vitro quantified determination of $\beta$-amyloid 42 peptides, a biomarker of neuro-degenerative disorders, in PBS and human serum using a simple, cost-effective thin gold film biosensor. Biosensors. 2017;7(3):1-11.

171. Mustafa MK, Nabok A, Parkinson D, Tothill IE, Salam F, Tsargorodskaya A. Detection of $\beta$-amyloid peptide (1-16) and amyloid precursor protein (APP770) using spectroscopic ellipsometry and QCM techniques: a step forward towards Alzheimers disease diagnostics. Biosens Bioelectron. 2010;26(4):1332-6.

172. Carlin N, Martic-Milne S. Anti-tau antibodies based electrochemical sensor for detection of tau protein biomarkers. J Electrochem Soc. 2018;165(12):G3018-G25.

173. Hinrichs K, Eichhorn K-J. Ellipsometry of functional organic surfaces and films: Springer; 2018.
174. Waikar SS, Sabbisetti VS, Bonventre JV. Normalization of urinary biomarkers to creatinine during changes in glomerular filtration rate. Kidney Int. 2010;78(5):486-94.

175. Fonteh A, Harrington R, Tsai A, Liao P, Harrington M. Free amino acid and dipeptide changes in the body fluids from Alzheimer's disease subjects. Amino Acids. 2007;32(2):213-24.

176. Zhang C, Nestorova G, Rissman RA, Feng J. Detection and quantification of 8-Hydroxy-2'-deoxyguanosine in Alzheimer's transgenic mouse urine using capillary electrophoresis. Electrophoresis. 2013;34(15):2268-74.

177. Takata M, Nakashima M, Takehara T, Baba H, Machida K, Akitake Y, et al. Detection of amyloid $\beta$ protein in the urine of Alzheimer's disease patients and healthy individuals. Neurosci Lett. 2008;435(2):126-30.

178. Ghanbari H, Ghanbari K, Beheshti I, Munzar M, Vasauskas A, Averback P. Biochemical assay for AD7C-NTP in urine as an Alzheimer's disease marker. J Clin Lab Anal. 1998;12(5):285-8.

179. Youn YC, Park K-W, Han S-H, Kim S. Urine neural thread protein measurements in Alzheimer disease. J Am Med Dir Assoc. 2011;12(5):372-6.

180. Levy S, McConville M, Lazaro GA, Averback P. Competitive ELISA studies of neural thread protein in urine in Alzheimer's disease. J Clin Lab Anal. 2007;21(1):24-33.

181. Ku BD, Kim H, Kim YK, Ryu HU. Comparison of urinary Alzheimerassociated neural thread protein (AD7c-NTP) levels between patients with amnestic and nonamnestic mild cognitive impairment. Am J Alzheimer's Dis Other Dement. 2019;35:1-7.

182. Da Silva W, Brett CMA. Novel biosensor for acetylcholine based on acetylcholinesterase/poly(neutral red) - deep eutectic solvent/Fe2O3 nanoparticle modified electrode. J Electroanal Chem. 2020;872:114050

183. Murillo Pulgarín JA, Alañón Molina A, Jiménez García E, García Gómez $L$. A sensitive resonance Rayleigh scattering sensor for dopamine in urine using upconversion nanoparticles. Raman Spectrosc. 2020:51(3):406-13.

184. Wood H. Could tear proteins be biomarkers for Alzheimer disease? Nat Rev Neurol. 2016;12(8):432-

185. Kenny A, Jiménez-Mateos EM, Zea-Sevilla MA, Rábano A, Gili-Manzanaro P, Prehn JHM, et al. Proteins and microRNAs are differentially expressed in tear fluid from patients with Alzheimer's disease. Sci Rep. 2019;9(1):15437.

186. Zhou L, Beuerman RW. Tear analysis in ocular surface diseases. Prog Retin Eye Res. 2012;31(6):527-50.

187. Punj S, Sidhu D, Bhattacharya D, Wang M, Wong PK. An electrochemical biosensor platform for rapid immunoanalysis of physiological fluids. Oj-Nano. 2020;1:31-7.

188. Kalló G, Emri M, Varga Z, Ujhelyi B, Tőzsér J, Csutak A, et al. Changes in the chemical barrier composition of tears in Alzheimer's disease reveal potential tear diagnostic biomarkers. PLoS ONE. 2016;11(6):e0158000.

189. Gao W, Emaminejad S, Nyein HYY, Challa S, Chen K, Peck A, et al. Fully integrated wearable sensor arrays for multiplexed in situ perspiration analysis. Nature. 2016;529(7587):509-14.

190. Mehta D, Malik AB. Signaling mechanisms regulating endothelial permeability. Physiol Rev. 2006;86(1):279-367.

191. Kim J, Jeerapan I, Imani S, Cho TN, Bandodkar A, Cinti S, et al. Noninvasive alcohol monitoring using a wearable tattoo-based iontophoreticbiosensing system. ACS Sens. 2016;1 (8):1011-9.

192. Lei Y, Butler D, Lucking MC, Zhang F, Xia T, Fujisawa K, et al. Single-atom doping of MoS2 with manganese enables ultrasensitive detection of dopamine: experimental and computational approach. Sci Adv. 2020;6(32):eabc4250.

193. Elmståhl S, Winge L. Increased sweat sodium concentration in patients with Alzheimer's disease. Dement Geriatr Cogn Disord. 1993;4(1):50-3.

194. François M, Bull CF, Fenech MF, Leifert WR. Current state of saliva biomarkers for aging and Alzheimer's disease. Curr Alzheimer Res. 2019;16(1):56-66

195. Shi M, Sui Y-T, Peskind ER, Li G, Hwang H, Devic I, et al. Salivary Tau Species are Potential Biomarkers of Alzheimer's Disease. J Alzheimer's DisJ. 2011;27:299-305.

196. Lee M, Guo J-P, Kennedy K, McGeer EG, McGeer PL. A method for diagnosing Alzheimer's disease based on salivary amyloid- $\beta$ protein 42 levels. J Alzheimer's DisJ. 2017;55(3):1175-82.

197. Fleitas C, Piñol-Ripoll G, Marfull P, Rocandio D, Ferrer I, Rampon C, et al. proBDNF is modified by advanced glycation end products in 
Alzheimer's disease and causes neuronal apoptosis by inducing p75 neurotrophin receptor processing. Mol Brain. 2018;11(1):1-16.

198. Oh YS, Turner RJ. Effect of $Y$-secretase inhibitors on muscarinic receptormediated calcium signaling in human salivary epithelial cells. Am J Physiol Cell Physiol. 2006;291(1):C76-82.

199. Sabbagh MN, Shi J, Lee M, Arnold L, Al-Hasan Y, Heim J, et al. Salivary beta amyloid protein levels are detectable and differentiate patients with Alzheimer's disease dementia from normal controls: preliminary findings. BMC Neurol. 2018:18(1):155.

200. Kawasaki T, Tsukiyama K, Irizawa A. Dissolution of a fibrous peptide by terahertz free electron laser. Sci Rep. 2019;9(1):10636.

201. Yan Z, Zhou Z, Wu Q, Chen ZB, Koo EH, Zhong S. Presymptomatic increase of an extracellular RNA in blood plasma associates with the development of Alzheimer's disease. Curr Biol. 2020;30(10):1771-82.

202. Berdyyeva T, Xia C, Taylor N, He Y, Chen G, Huang C, et al. PET imaging of the $\mathrm{P} 2 \times 7$ ion channel with a novel tracer [18F]JNJ-64413739 in a rat model of neuroinflammation. Mol Imaging Biol. 2019;21(5):871-8.
203. Doraiswamy PM, Narayan VA, Manji HK. Mobile and pervasive computing technologies and the future of Alzheimer's clinical trials. NPJ Digit Med. 2018;1(1):1.

204. Kourtis LC, Regele OB, Wright JM, Jones GB. Digital biomarkers for Alzheimer's disease: the mobile/wearable devices opportunity. NPJ Digit Med. 2019;2(1):9.

205. Goldsmith BR, Locascio L, Gao Y, Lerner M, Walker A, Lerner J, et al. Digital biosensing by foundry-fabricated graphene sensors. Sci Rep. 2019;9(1):1-10

\section{Publisher's note}

Springer Nature remains neutral with regard to jurisdictional claims in published maps and institutional affiliations.
Ready to submit your research? Choose BMC and benefit from:

- fast, convenient online submission

- thorough peer review by experienced researchers in your field

- rapid publication on acceptance

- support for research data, including large and complex data types

- gold Open Access which fosters wider collaboration and increased citations

- maximum visibility for your research: over $100 \mathrm{M}$ website views per year

At BMC, research is always in progress.

Learn more biomedcentral.com/submissions 